\title{
Quaternary Sedimentation in the St. Lawrence Estuary and Adjoining Areas, Eastern Canada: An Overview Based on High-Resolution Seismo-Stratigraphy \\ Sédimentation quaternaire dans l'estuaire du Saint-Laurent et les régions circumvoisines : étude fondée sur la stratigraphie sismique à haute résolution Quaternär-Sedimentbildung in der Gezeitenmündung des Sankt-Lorenz-Stroms und angrenzenden Gebieten, Ost-Kanada: Eine Übersicht, die sich auf Seismo-Stratigraphie mit hoher Auflösung stützt
}

\author{
James P. M. Syvitski et Dan B. Praeg
}

Volume 43, numéro 3, 1989

Le $\mathrm{VI}^{\mathrm{e}}$ Congrès de l'Association québécoise pour l'étude du Quaternaire

URI : https://id.erudit.org/iderudit/032784ar

DOI : https://doi.org/10.7202/032784ar

Aller au sommaire du numéro

Éditeur(s)

Les Presses de l'Université de Montréal

ISSN

0705-7199 (imprimé)

1492-143X (numérique)

Découvrir la revue

Citer cet article

Syvitski, J. P. M. \& Praeg, D. B. (1989). Quaternary Sedimentation in the St. Lawrence Estuary and Adjoining Areas, Eastern Canada: An Overview Based on High-Resolution Seismo-Stratigraphy. Géographie physique et Quaternaire, 43(3), 291-310. https://doi.org/10.7202/032784ar

\section{Résumé de l'article}

Le présent article se fonde sur des profils effectués par sismique reflection sur 5700 kilomètres dans le nord-ouest du golfe du Saint-Laurent. La séquence quaternaire, parfois absente, peut ailleurs avoir plus de 1,3 kilomètre d'épaisseur. On a relevé cinq grandes unités stratigraphiques dont la nature et la répartition varient. Liées à l'évolution de l'inlandsis du Wisconsinien supérieur, elles se présentent comme suit: unité 1 : sédiments de contact renfermant des sédiments comprimés par le glacier et d'autres déposés par lui; unité 2: sédiments proximaux grossiers, déposés soit en une couche mince et concordante durant le retrait rapide d'un front, soit sous forme de cône marquant la position d'un front stable; unité 3: sédiments distaux fins, déposés par des langues d'eau de fusion dans une mer à niveaux élevés et dont la glace fondait rapidement; unité 4: sédiments deltaïques paraglaciaires révélant la fusion de glaces continentales et la formation rapide et concomitante de deltas dans une mer accusant de fortes baisses de niveau : unité 5: sédiments postglaciaires révélant le triage de zones peu profondes et le dépôt, en profondeur, de boues riches en matières organiques, dans des conditions rappelant celles d'aujourd'hui. Un modèle, exposant les étapes de

sédimentation associées au retrait d'un inlandsis, tient compte des dynamiques associées à la première avancée glaciaire, à la position glaciaire finale, au retrait du front glaciaire, à la stabilité du front pendant le retrait, à la fusion de l'inlandsis et à la sédimentation postglaciaire dans une mer aux niveaux changeants. 


\section{QUATERNARY SEDIMENTATION IN THE ST. LAWRENCE ESTUARY AND ADJOINING AREAS, EASTERN CANADA: AN OVERVIEW BASED ON HIGH RESOLUTION SEISMO-STRATIGRAPHY*}

James P. M. SYVITSKI and Dan B. PRAEG, Geological Survey of Canada, Bedford Institute of Oceanography, Dartmouth, Nova Scotia B2Y 4A2.

\begin{abstract}
The regional Quaternary seismo-stratigraphy of NW Gulf of St. Lawrence, based on 5700 line $\mathrm{km}$ of high resolution seismic reflection profiles, is described. The Quaternary sequence can be locally missing or can exceed $1.3 \mathrm{~km}$ in thickness. Five major stratigraphic units are recognized, which vary in their character and distribution so that at any location a variety of bedrock types may be overlain by a distinctive Quaternary sequence. These units relate to the advance and retreat of the Late Wisconsinan Ice Sheet. We interpret these units as: Unit 1 , recording the presence of grounded glacial ice, including ice-loaded and ice-deposited sediments. Unit 2, ice-proximal coarse-grained sediment deposited either as a thin, conformable layer during the rapid retreat of an ice terminus, or as a wedge-shaped fan marking the position of an ice front still stand. Unit 3, ice-distal fine-grained sediment deposited from meltwater plumes at times of elevated sea levels and rapidly ablating sea ice. Unit 4, paraglacial deltaic sediment marking the melting of terrestrially-based ice caps, and the concommittant growth of deltas, rapidly prograding into a seaway undergoing rapidly falling sea levels. Unit 5 , postglacial sediment reflecting the winnowing of shallow areas and deposition of organic-rich mud in deep basins, under modern sea level and oceanographic conditions. A conceptual model dealing with the deposition of sediment associated with the withdrawal of a continental ice sheet is developed. The model includes the dynamics associated with the initial ice advance, terminal ice dynamics, retreat of the ice terminus, stable ice-fronts during the recessional phase, ice sheets ablating on land, and postglacial sedimentation under conditions of fluctuating sea levels.
\end{abstract}

RÉSUMÉ Sédimentation quaternaire dans l'estuaire du Saint-Laurent et les régions circumvoisines: étude fondée sur la stratigraphie sismique à haute résolution. Le présent article se fonde sur des profils effectués par sismique réflection sur 5700 kilomètres dans le nordouest du golfe du Saint-Laurent. La séquence quaternaire, parfois absente, peut ailleurs avoir plus de 1,3 kilomètre d'épaisseur. On a relevé cinq grandes unités stratigraphiques dont la nature et la répartition varient. Liées à l'évolution de l'inlandsis du Wisconsinien supérieur, elles se présentent comme suit: unité 1 : sédiments de contact renfermant des sédiments comprimés par le glacier et d'autres déposés par lui; unité 2 : sédiments proximaux grossiers, déposés soit en une couche mince et concordante durant le retrait rapide d'un front, soit sous forme de cône marquant la position d'un front stable; unité 3 : sédiments distaux fins, déposés par des langues d'eau de fusion dans une mer à niveaux élevés et dont la glace fondait rapidement; unité 4 : sédiments deltaïques paraglaciaires révélant la fusion de glaces continentales et la formation rapide et concomitante de deltas dans une mer accusant de fortes baisses de niveau : unité 5 : sédiments postglaciaires révélant le triage de zones peu profondes et le dépôt, en profondeur, de boues riches en matières organiques, dans des conditions rappelant celles d'aujourd'hui. Un modèle, exposant les étapes de sédimentation associées au retrait d'un inlandsis, tient compte des dynamiques associées à la première avancée glaciaire. à la position glaciaire finale, au retrait du front glaciaire, à la stabilité du front pendant le retrait, à la fusion de l'inlandsis et à la sédimentation postglaciaire dans une mer aux niveaux changeants.
ZUSAMMENFASSUNG Quaternär-Sedimentbildung in der Gezeitenmündung des Sankt-Lorenz-Stroms und angrenzenden Gebieten, Ost-Kanada: Eine Übersicht, die sich auf Seismo-Stratigraphie mit hoher Auflösung stützt. Die regionale Quaternär Seismo-Stratigraphie des Nordwestens vom Sankt-Lorenz-Golf wird beschrieben, gestützt auf $5700 \mathrm{~km}$ lange seismische Reflexionsprofile mit hoher Auflösung. Die QuaternärSequenz kann stellenweise fehlen oder auch über $1.3 \mathrm{~km}$ dick sein. Fünf stratigraphische Haupt einheiten werden bestimmt. Einheit 1 , welche das Vorhandensein von glazialem bodeneis einschliesslich durch Eis komprimierte und durch Eis abgelagerte Sedimente dokumentiert. Einheit 2, ein grobgekörntes Eisproximal-Sediment, das entweder als eine dünne, gleichgelagerte Schicht während des schnellen Rückzugs eines Eisterminus abgelagert wurde, oder als ein keilförmiger Fächer, der den Stillstand einer Eisfront markiert. Einheit 3, ein feinkörniges Eis-DistalSediment, das von Schmelzwasserzungen in Zeiten erhöhter Meeresspiegel und rasch schmelzenden Meereises abgelagert wurde. Einheit 4, ein paraglaziales Delta-Sediment, welches das Schmelzen von auf dem Festland gelagerten Eiskappen markiert und das damit verbundene Anwachsen der Deltas, die schnell zu einem Seeweg vorrückten und schnell fallenden Meeresspiegeln ausgesetzt waren. Einheit 5, ein postglaziales Sediment, das das Aussortieren seichter Gebiete spiegelt sowie Ablagerung von organisch reichem Schlamm in tiefen Becken und das unter modernen Meeresspiegel - und ozeanographischen Bedingungen. Es wird ein Begriffsmodell entwickelt, das sich mit der Ablagerung von Sediment im Zusammenhang mit dem Rückzug einer kontinentalen Eisdecke befasst. 


\section{INTRODUCTION}

This article provides an overview of the distribution and acoustic properties of the unconsolidated Quaternary sediments flooring the St. Lawrence Estuary and adjoining basins (Fig. 1a). The discussion is based primarily on a grid of highresolution reflection seismic profiles obtained between 1984 and 1988 (Fig. 1c). Marine cores collected during this period and during the extensive seafloor sampling program of Loring (Loring and Nota, 1973; Loring 1975) additionally provide limited stratigraphic control. This work forms part of on-going regional marine surveys on the eastern Canadian continental margin, undertaken by the Geological Survey of Canada, that focus on the style of sediment deposition during the Quaternary (e.g. Fader et al., 1982; Josenhans et al., 1986; King and Fader, 1986; Praeg et al., 1986; Syvitski et al., 1987a; Vilks et al., 1987).

The most recent synthesis of terrestrial research concerning the Late Wisconsinan history of the Laurentide Ice Sheet within our study area is that of Dyke and Prest (1987). In their scenario, the Laurentian Trough was the confluence of ice domes to the north (Laurentian) and south (Appalachian). The ice sheet attained its penultimate extent by $18 \mathrm{ka}$, remained relatively stable between 18 to $14 \mathrm{ka}$, and advanced to a maximum position ca. $14.5 \mathrm{ka}$, including onto Anticosti Island (Fig. 1b). Between 14 to $13 \mathrm{ka}$, a calving margin retreated up the estuary to a still stand position off the mouth of the Saguenay, thus separating the Laurentide ice into two domes on either side of the Goldthwait Sea. Goldthwait Sea refers to the body of water in the Gulf of St. Lawrence and estuary that came into existence during the time of deglaciation when sea levels were much higher than today (i.e. the Late Wisconsinan marine limit). By $12 \mathrm{ka}$, the Laurentian ice conduit had calved back to near Québec City. The Appalachian ice dome had, by then, withdrawn from the Goldthwait Sea and was completely ablated by $11 \mathrm{ka}$. The Laurentian dome withdrew from most of the Goldthwait Sea by $10 \mathrm{ka}$, and finally from Mer de Laflamme (local Late Wisconsinan marine limit), occupying the present Saguenay region, by $8.4 \mathrm{ka}$.

Relative sea level fluctuations during the Late Wisconsinan have been highly variable along the coast, especially between the north and south shores of the Estuary. Sea levels reached a maximum of $180 \mathrm{~m}$ asl (near Québec) during the initial stages of ice retreat, $125 \mathrm{~m}$ at Matane, and $75 \mathrm{~m}$ at SteAnne-des-Monts along the Gaspé Peninsula (Dionne, 1988). Between 13 and 9 ka the rate of land emergence was $3 \mathrm{~cm} \mathrm{a}^{-1}$ (Dionne, 1988). A low sea level stand $(\approx 5 \mathrm{~m}$ below present datum) occurred ca. 7 to $6 \mathrm{ka}$, followed by a $10 \mathrm{~m}$ marine transgression ca. $5 \mathrm{ka}$, which persisted until sea level reached present levels at $3 \mathrm{ka}$ (Dionne, 1988).

The Laurentian Trough is part of the St. Lawrence Lowlands, which include Anticosti Island and separate the Laurentian Highlands of the Canadian Precambrian Shield in the north from the Appalachian Mountains and Uplands to the south. The Laurentian Highlands of the Shield are dissected by shoretransverse troughs with 100's of m relief, a submerged example of which is the Saguenay Fjord, a $90 \mathrm{~km}$ long, 1 to $6 \mathrm{~km}$ wide basin. These troughs direct regional drainage into a series of deltas, the largest of which is the Manicouagan, which are presently prograding offshore (Syvitski, 1986). The Appalachian Mountains presently provide relatively little water or sediment to the Laurentian Channel but supply the partially-mixed estuaries of the Gaspé including the $6,000 \mathrm{~km}^{2}$ Baie des Chaleurs. The present St. Lawrence Estuary extends from Québec City to the widening of the channel into the northwest Gulf of St. Lawrence west of Anticosti Island, and is divided into upper and lower parts at the entrance to the Saguenay (d'Anglejan and Smith, 1973). Literature reviews of the marine geology of this area can be found in Loring (1975), Syvitski et al. (1983a) and Syvitski (1986).

The St. Lawrence Estuary was a key conduit for the Late Wisconsinan ice advance ca. 25 to $18 \mathrm{ka}$, and the NW Gulf received sediment-laden discharge from at least three ice margins: the Gaspé, the Laurentian and the Anticosti margins. Terrestrial evidence used to interpret the marine maximum of ice extent or regional ice dynamics have not always been conclusive. Thus there are many Quaternary-related problems that vertically and horizontally-continuous marine data could help resolve. Major questions include: (1) during the last ice advance was the ice terminus floating or grounded? (2) if grounded, were previous marine Quaternary deposits eroded or simply over-ridden by the advancing ice sheet? (3) what is the thickness and extent of glacial till within the marine environment? (4) what was the oceanographic environment like during the last 18,000 years? and (5) what are the major processes of deposition that occur during the retreating phase of a temperate ice sheet?

\section{METHODS}

The principal source of information is a grid of multiparameter survey lines (Fig. 1C) collected during four Bedford Institute of Oceanography (BIO) cruises since 1984 (Hoskin et al., 1984; Praeg et al., 1987a,b; Currie and Beaver, 1988). In addition, single-parameter grids collected by the Canadian Hydrographic Service, and by d'Anglejan and Brisebois (1978), were used respectively in Baie des Chaleurs (Syvitski et al., 1987a) and in the upper St. Lawrence Estuary (Praeg et al., in prep.). Other published seismic reflection surveys in the study area are scattered (see Loring and Nota, 1973).

During our $\mathrm{BIO}$ cruises up to 4 types of reflection information were collected simultaneously. Filtered echoes were recorded on EPC or Raytheon graphic recorders, and in most cases the raw analog echoes were recorded on HP or RACAL multichannel tape recorders. Survey lines were run at speeds of 6-10 km/hr, and were positioned by fixes from a combination of radar ( $\pm 25 \mathrm{~m}$ accuracy nearshore to $\pm 250 \mathrm{~m}$ near the limits of radar range) and Loran $\mathrm{C}( \pm 50 \mathrm{~m}$ where available), supplemented by occasional transit satellite fixes. Air gun seismic reflection profiles were collected using a Bolt Associates model $600 \mathrm{~B}$ gun with 10,20 or $40 \mathrm{in}^{3}$ chambers fired at $\approx 1900 \mathrm{PSI}$ and a $2-3 \mathrm{~s}$ rate, and a single channel NSRF $6 \mathrm{~m}$ hydrophone; this array was towed at surface $10-30 \mathrm{~m}$ astern. The returns from the broadband energy source (most energy in the range 80 to $1000 \mathrm{~Hz}$ ) were typically filtered into two graphic records (100 to $550 \mathrm{~Hz}$ and 300 to $1500 \mathrm{~Hz}$ ). 

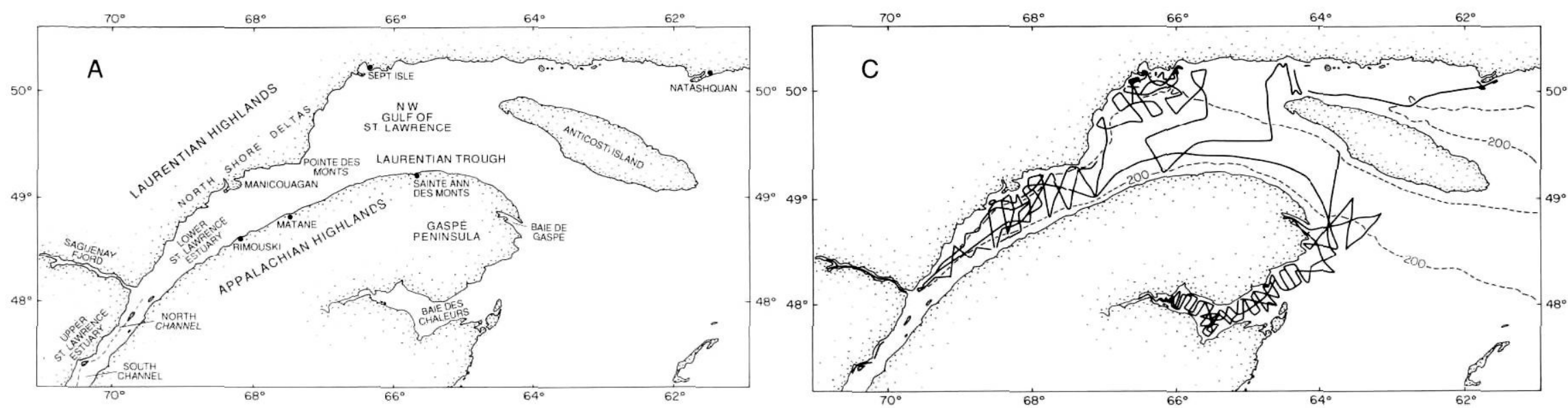

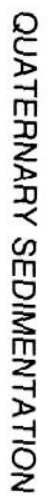

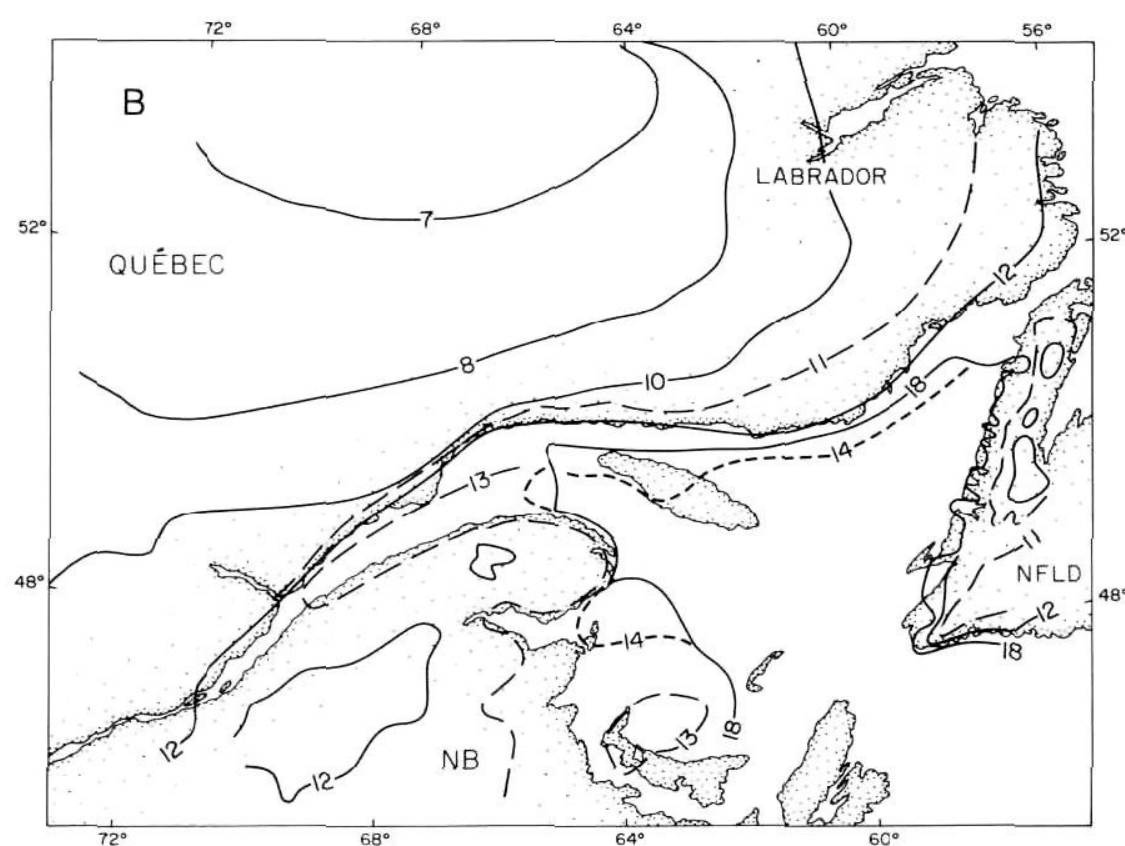

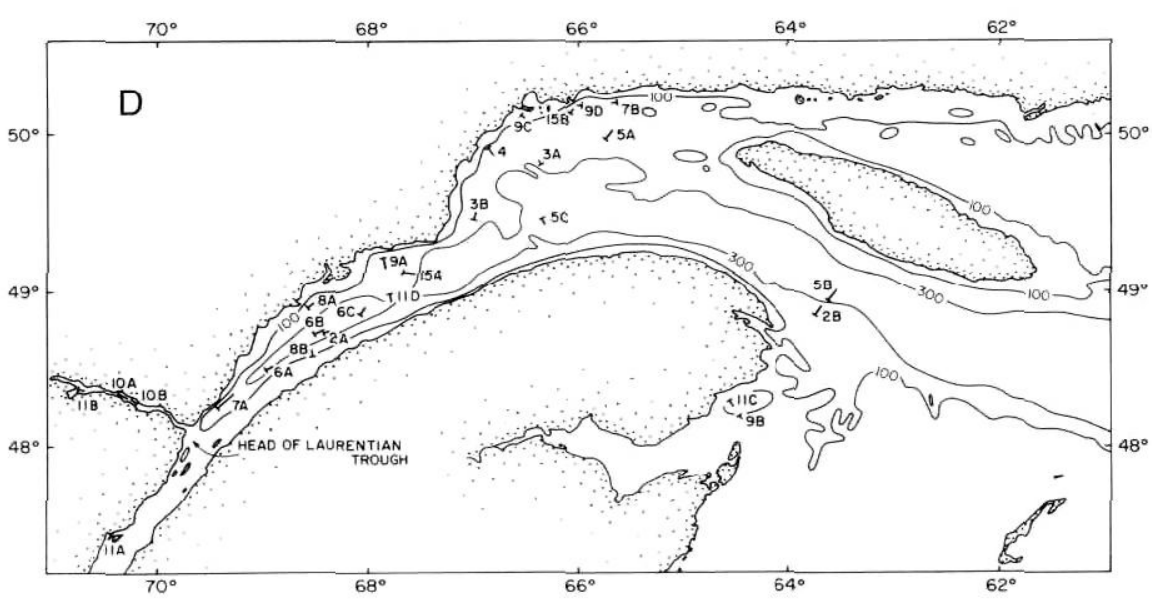

FIGURE 1. Study area, A: place names used in text; B: positions of the margin of the Laurentide Ice Sheet through the Late Quaternary as proposed by Dyke and Prest (1987): $\mathrm{C}$ : geophysical track coverage; and D: profiles used in subsequent figures.

Région étudiée. A: toponymes mentionnés dans le texte; B: marges de l'inlandsis laurentidien au Quaternaire supérieur, comme le proposent Dyke et Prest (1987); C couverture spatiale des profils géophysiques; $D$ : profils représentés dans les figures suivantes. 
Huntec deep tow seismic reflection profiles (Hutchins et al., 1976) were collected from a 'fish' containing either a 500 or $1000 \mathrm{~J}$ high resolution boomer fired at a $0.75 \mathrm{~s}$ rate and two single channel hydrophones, internal (maximum resolution) and external (maximum penetration); the fish was towed up to $500 \mathrm{~m}$ astern and 50 to $200 \mathrm{~m}$ above the seabed to a maximum depth of $200 \mathrm{~m}$. The signal returns from the broadband energy source $(0.8$ to $10 \mathrm{kHz}$ ) were typically filtered into two graphic records (internal hydrophone: 0.5 to $10 \mathrm{kHz}$, and external hydrophone array: 0.5 to $3 \mathrm{kHz}$ ). Sidescan sonar seabed images were collected using dual 50 or $100 \mathrm{kHz}$ Klein transducers fired at a $0.2 \mathrm{~s}$ rate to insonify a $300 \mathrm{~m}$ swath; the transducers were located on the Huntec fish or, in one case, on a separate towfish. Echosounder records were collected using a $12 \mathrm{kHz}$ transducer mounted on the ships' hull.

Huntec and air gun records were the principal data used in establishing our seismo-stratigraphic units, along with sparker records from the upper St. Lawrence Estuary (d'Anglejan and Brisebois, 1978). Huntec records provide up to $100 \mathrm{~m}$ of high resolution ( 30 to $50 \mathrm{~cm}$ vertical, 1 to $2 \mathrm{~m}$ horizontal) subbottom information. Air gun (and sparker) records have lower resolution (3 to $10 \mathrm{~m}$ vertical, 4 to $10 \mathrm{~m}$ horizontal), but provide penetration to the bedrock surface almost everywhere. Throughout this article thicknesses are reported in metres, for conceptual ease. Thicknesses were calculated using an assumed velocity of $1.5 \mathrm{~km} \mathrm{~s}^{-1}$; this is approximately the velocity of sound in water, whereas actual sediment velocities may vary from 1.5 to $2.0 \mathrm{~km} \mathrm{~s}^{-1}$ (Hamilton, 1985), so that thicknesses represent minimum estimates.

We define seismo-stratigraphic units as successive intervals that can be recognized and traced on the basis of distinctive acoustic attributes, bedding styles, and/or unit geometry. Acoustic attributes are the presence and relative strength of both coherent reflectors (stratification) and incoherent backscatter (tone), coherency being limited by the resolution of the system. Both types of reflection impart information about changes in sediment texture or geotechnical properties; the absence of reflections implies a homogenous sediment. Bedding styles refer to the internal acoustic stratification in relation to the bounding surfaces of the unit. Unit geometry is the nature of the upper reflector and its relation to the basal reflector, and the relation of the interval as a whole to basal topography. Units were established at one or more areas of well-defined or typical section, and then traced laterally to establish a regional stratigraphy within which units often display facies variability in their acoustic attributes, bedding style, and geometry. Interpretation of our seismic units is based on their acoustic attributes, their stratigraphic position and lithologic information (Hein and Syvitski, 1988; Praeg et al., 1987a,b).

\section{SEISMO-STRATIGRAPHIC UNITS}

Unconsolidated Quaternary sediments are recognized throughout the St. Lawrence study area, overlying the surface of sedimentary or crystalline bedrock. Regional variations in the thickness of the Quaternary sequence reflect the changing scales and styles of sedimentation across the area (see Fig. 12). Quaternary sediments exceed a thickness of $1.4 \mathrm{~km}$ in the Saguenay, at least $350 \mathrm{~m}$ in the North Channel, and $400 \mathrm{~m}$ at the head of the Laurentian Trough, but thin down the axis and towards the margins of the Trough, and are generally less than $50 \mathrm{~m}$ thick by the entrance to the NW Gulf. Sediments remain generally less than $50 \mathrm{~m}$ thick across the NW Gulf basin, and in Baie des Chaleurs, but thicken to $130 \mathrm{~m}$ east of Baie des Chaleurs on the south wall of the Laurentian Trough.

Five major seismo-stratigraphic units are recognized within the Quaternary sequence of the St. Lawrence Estuary and adjoining areas. The units together record at least one deglacial cycle, during which ice retreated from a maximum position at the limits of the study area to a stable position at the head of the Laurentian Trough and along the margins of the Goldthwait Sea, and then withdrew completely. The units are described and justified below as: (1) ice-contact sediments that record the presence of grounded glacial ice; (2) ice-proximal sediments; (3) ice-distal sediments; (4) paraglacial deltaic sediments; and (5) postglacial sediments. The units vary regionally in their character and occurrence, so that at any given location the bedrock may be overlain by a distinctive sequence in which all, none or a combination of the units are present.

\section{BEDROCK}

The bedrock surface at the base of the Quaternary sequence is recognized either as acoustic basement, characterized by variable relief and lack of penetration (Fig. 2a), or as an angular unconformity truncating deformed stratified sequences (Fig. 2b). In the upper St. Lawrence Estuary, bedrock is not continuously observed. Acoustic basement occurs beneath the Saguenay, beneath the Laurentian Trough and adjoining shelves of the lower St. Lawrence Estuary downriver to Rimouski/Manicouagan, along parts of the north shore east from Manicouagan, and east of the Gaspé Peninsula. It represents an extension of the crystalline rocks of the Precambrian Shield in the north, and highly deformed sedimentary and volcanic rocks of the Appalachian Orogen in the south (Douglas, 1970). In the lower estuary adjacent to Rimouski the contact between these two provinces, known as Logan's Line, is marked by the change in the basement morphology, from up to 100's of metres of shore-parallel relief beneath the southern shelf, to a lesser relief $(<50 \mathrm{~m})$ beneath the trough and shelf to the north (Fig. 2a).

Seaward from Rimouski/Manicouagan and from the north shore, acoustic basement gives way to an angular unconformity at the surface of gently folded (dips generally $<10^{\circ}$ ) and locally faulted strata (Fig. 2b). These strata underlie the NW Gulf of St. Lawrence, west, north and south of Anticosti, and are interpreted as an extension of Ordovician and Silurian limestones and shales of the Anticosti Platform. This concurs with previous work by Loring (1975), who was able to use drill samples to infer the contact between Ordovician and Silurian strata south of Anticosti Island. The contact between this bedrock type and acoustic basement generally appears gradational. Acoustically similar strata observed beneath an angular unconformity in Baie des Chaleurs are correlated with the post-orogenic Carboniferous sedimentary rocks that form 

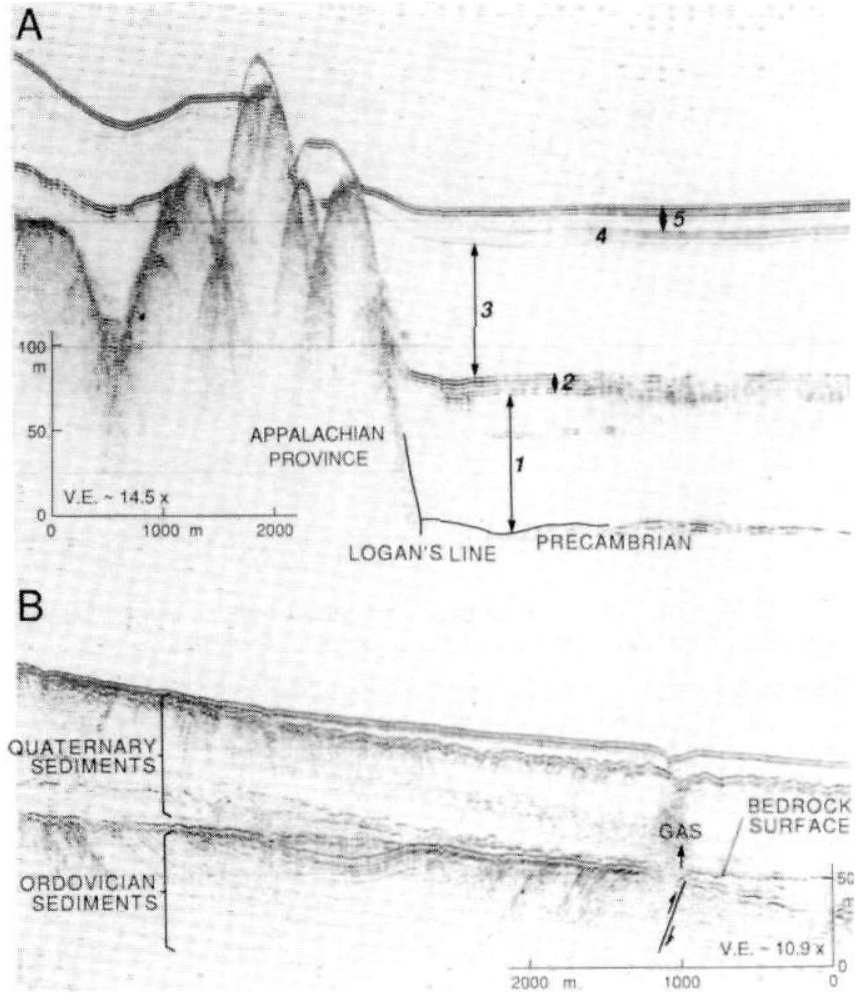

FIGURE 2. Acoustic basement or bedrock types encountered in our study area. A: Contact between the Precambrian crystalline and Ordovician sedimentary bedrock along Logan's Line; B: faulted and deformed strata of Ordovician-Silurian age. See Figures $3,4,5,6$, and 15 for further examples.

Substratum acoustique ou types de roche en place rencontrés: A: contact entre la roche précambrienne cristalline et la roche ordovicienne sédimentaire le long de la faille de Logan; B: couches d'âge ordovicien-silurien déformées et faillées. Voir aussi les figures $3,4,5,6$ et 15 .

the margins of the bay and much of eastern New Brunswick (Syvitski et al., 1987a).

The surface morphology of the various bedrock types is a product of the long-term history of erosion, including marine, fluvial and glacial processes. It has exerted an influence on both the local and regional distributions of the Quaternary units discussed below. The present regional bathymetry of the survey area is a muted reflection of the bedrock surface, which is dominated by the overdeepened Laurentian Trough, but includes a great variety of smaller basins, both within and adjacent to the Laurentian Trough. Such basins tend to be narrow and steep-sided, in areas of crystalline bedrock (acoustic basement), and broader and shallower in areas of sedimentary bedrock, although basins resulting from the north shore cuestas of Ordovician limestones and shales provide an important exception. The presence of these basins has influenced the distribution of subglacial deposits and subsequent glaciomarine and postglacial deposits. For example, the north shore cuestas provide numerous traps and little glaciomarine sediment appears to have been transported beyond this very rough subbottom relief.

\section{ICE CONTACT SEDIMENTS: UNIT 1}

Unit 1 is stratigraphically the lowermost unconsolidated layer. It is acoustically characterized by moderate to strong tone, poor to absent stratification, and by upper and lower bounding surfaces that are both complex and highly variable. The unit appears in either of two mutually exclusive unit geometries that we propose represent a depositional facies and an ice-loaded facies.

\section{Constructional Geometry (Depositional Facies)}

Deposits of this facies are acoustically unstratified sediments having distinct macro-relief (Figs. 3 and 4). Several forms are recognized. In one form they occur as a relatively thin interval (a few metres in thickness), generally of strong tone, often associated with fill of topographic depressions (cf. Fig. 4). We speculate that these are pockets of glacial till deposited as ground moraine in a manner similar to that outlined by Boulton (1975) for land-based ice flow over rough surfaces. The distribution of this form is common to nearshore banks, lateral margins of the Laurentian Trough, and the upper reaches of Baie Des Chaleurs.

In another form, isolated mounds and ridges of unstratified sediment with moderate acoustic tone occur on very smooth bedrock surfaces and in deep water $(>250 \mathrm{~m}$ ) (Fig. 3A). Such features are common to the NW Gulf. They may represent beaded esker deposits similar to the sediments described recently for an active glacier margin on the Svalbard Shelf (Pfirman and Solheim, 1989), or submarine drumlins as described for the shallow offshore of Nova Scotia (Piper et al., 1983). This interpretation is suggested by the lack of evidence of interfingering with, or lateral gradation into, the overlying ice-proximal unit 2 as might be expected during ice front sedimentation.

In another form, interconnected mounds of unstratified sediment with moderate acoustic tone occur in variable heights up to $10 \mathrm{~m}$. Such deposits show a strong inter-relationship with the ice-proximal (unit 2) sediments (Fig. 3B), and may represent push moraines formed in the marine environment (for dynamics see Boulton, 1986). Such a hypothesis would explain the variability in thickness of both the mounds and the overlying ice-proximal facies. These deposits occur only on the shallow margins $(<100 \mathrm{~m})$ surrounding the north shore of the eastern part of the study area.

Ice contact depositional forms may also occur as substantial wedge shaped deposits (20 to $40 \mathrm{~m}$ thick, $500 \mathrm{~m}$ to $2000 \mathrm{~m}$ in width), occasionally with discontinuous internal reflectors that suggest both an aggradational and progradational development. The ice-proximal unit $2-$ see description below is always found to be laterally equivalent (Fig. 4). These deposits can be traced laterally for many ten's of kilometres along one isobath $( \pm 10 \mathrm{~m})$. The deepest occurrence is off Sept-Îles in $180 \mathrm{~m}$ of water (equivalent to a water depth of $290 \mathrm{~m} c a .12 \mathrm{ka}$ ). These deposits can be correlated onshore to substantial frontal-dump moraines and ice-contact deposits (Dredge, 1983). We suggest, that these deposits are ice contact fans or frontal-dump moraines that mark equilibrium positions (still stands) of the ice margin, where the rates of ice front 

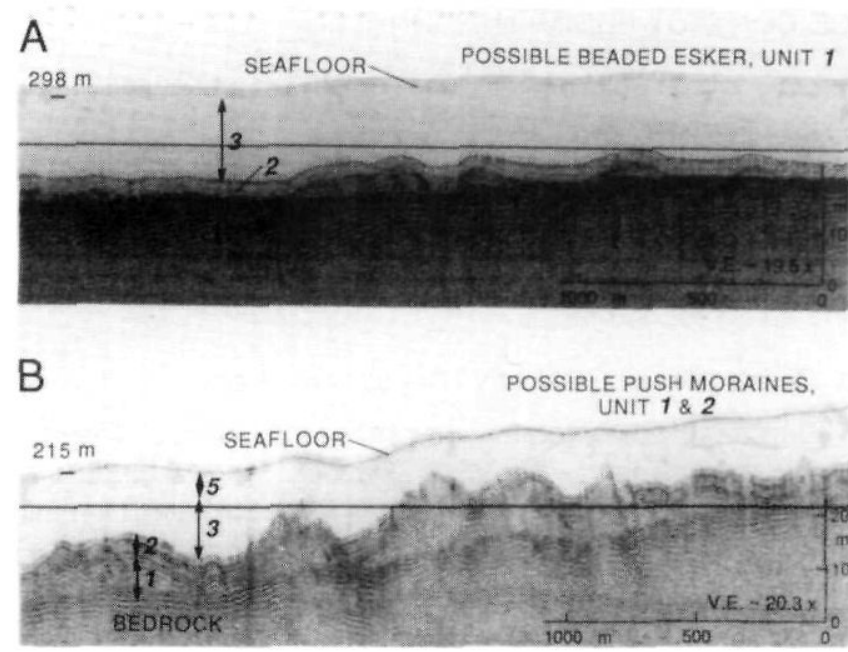

FIGURE 3. Huntec profiles of unit 1, Ice Contact Depositional Facies, from NW Gulf of St. Lawrence: A: possible beaded esker; B: pushed moraines.

Profils prélevés dans l'unité 1 par dispositif Huntec. Faciès sédimentaire de contact glaciaire, dans le nord-ouest du golfe du SaintLaurent: A: bourrelets signalant un esker probable; $B$ : moraines de poussée.

melting plus iceberg calving balanced the rate of ice supply. This hypothesis is further supported by the fact that these deposits only occur on the leading edge of bathymetric slopes (Fig. 4). In Baie des Chaleurs large linear ridges of unstratified sediment up to $30 \mathrm{~m}$ thick and kilometres long occur within overdeepened bedrock troughs. These ridges also have a diagnostic interfingering relationship with the overlying iceproximal sediments of unit 2, and may represent frontal dump deposits along the former margins of the Gaspé ice dome. The dynamics in the formation of frontal-dump moraines are presented in Syvitski (1989).

In still other cases, large accumulations of unit 1 contain continuous reflectors which may relate to multiple events, whether from readvances of the same glacier, or through the interaction of glaciers flowing from separate ice domes or directions (Fig. 5). An example is from a bank offshore of Sept-Îles in $170 \mathrm{~m}$ of water (Fig. 5a). A number of major reflectors can be identified including one nearsurface interval that has similar acoustic attributes and geometry to that of a debris flow (cf. Syvitski and Farrow, 1989). The underlying bedrock shoal probably influenced the movement of the Laurentide Ice Sheet, providing a depositional location for morainal and stagnation deposits. As such, the major internal reflectors may represent erosional peneplanes or loading surfaces from readvancement of the ice sheet over previous deposits. Deposits in Maktak Fiord, Baffin Island, provide a modern analogue whereby a wet-based glacier overrode its previous deposits in subsequent surges (Boulton et al., 1976). The weight of the Maktak Glacier caused structural deformation of its previous morainal deposits and in such environments debris flows are often generated (Boulton and Eyles, 1979).

Another multiple event example is from the Gaspé side of the Laurentian Trough, south of Anticosti Island, where ice from the Gaspé ice dome may have interacted with deposits

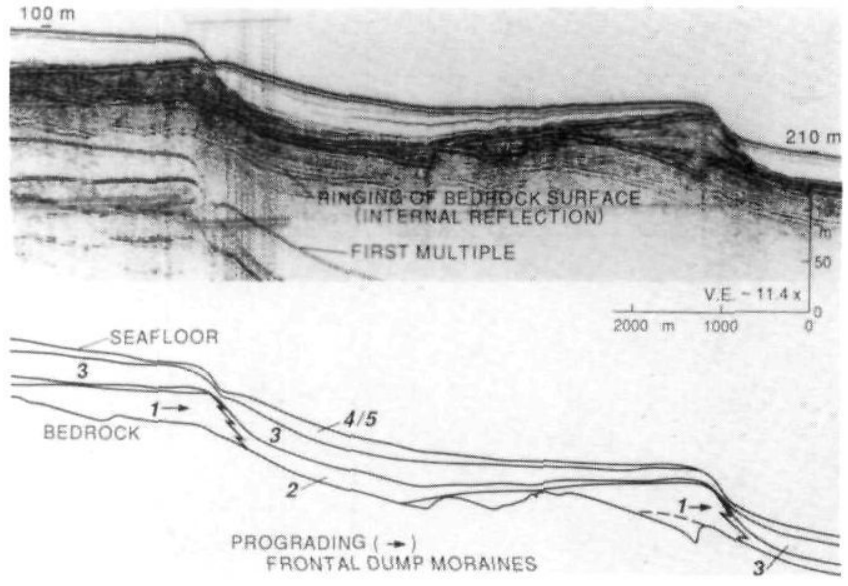

FIGURE 4. Airgun profile of two ice contact fans or frontal dump moraines, from NW Gulf of St. Lawrence near Sept-îles.

Profil de deux cônes proglaciaires ou de moraines frontales obtenu par fusil à air comprimé dans le nord-ouest du golfe du Saint-Laurent, près de Sept-îles.

from the Laurentian ice conduit (Fig. 5b). There the acoustic stratigraphy consists of: (i) a lower, possibly ice-loaded layer, identified as unit 1a, (ii) an ice-proximal, acoustically-stratified unit $2 a$, (iii) a second ice contact deposit, unit (1b), present on the Gaspé shelf but absent from the Laurentian Trough, (iv) a second ice-proximal, acoustically-stratified, unit $2 \mathrm{~b}$, that appears to laterally interfinger with the ice contact deposit on the Gaspe shelf, and (v) surticial layers that reflect ice distal and Holocene sedimentation. The possible formation of unit $1 \mathrm{a}$ is discussed below under ice loaded facies. Unit $1 \mathrm{~b}$ may represent a lateral moraine complex associated with the Laurentian Trough ice conduit, or equally, the terminal moraine complex of the Late Wisconsinan Gaspé ice dome.

On the northern margin of the Laurentian Trough (Fig. 5c), ice contact sediment also appears to have been deposited in two separate episodes. Units $1 \mathrm{a}$ and $1 \mathrm{~b}$ are each overlain, and thus stratigraphically separated, by acoustically stratified sediment (unit 2). We interpret unit 1a as relating to deposition from the Laurentide Ice Sheet flowing off the north shore of the Gulf; unit $1 \mathrm{~b}$ may relate to sediment deposition from the Laurentian Trough ice conduit.

\section{Basin-Fill Geometry (Ice Loaded Facies)}

In the Laurentian Trough there exists a regionally continuous facies of unit 1 with acoustic properties and geometry distinct from the ice contact depositional facies described above. Acoustically this facies is also typically characterized by moderate to strong tone and lack of stratification, but it has an irregular surface reflector that is smooth on a large scale and independent of basement morphology (Fig. 6c). The contact with overlying unit 2 or 3 is usually distinct. We propose that this unit is composed of pre-Late Wisconsinan sediment deposited during a prior glacial or interglacial period.

In the Lower Estuary, the basin-fill facies of unit 1 exceeds $200 \mathrm{~m}$ in thickness near the head of the Laurentian Trough, but thins to $<10 \mathrm{~m}$ by Pointe-des-Monts. This configuration 


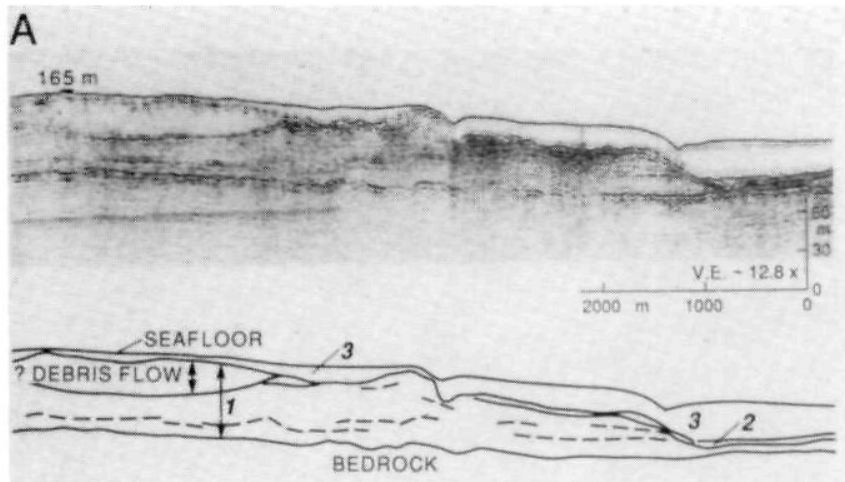

B

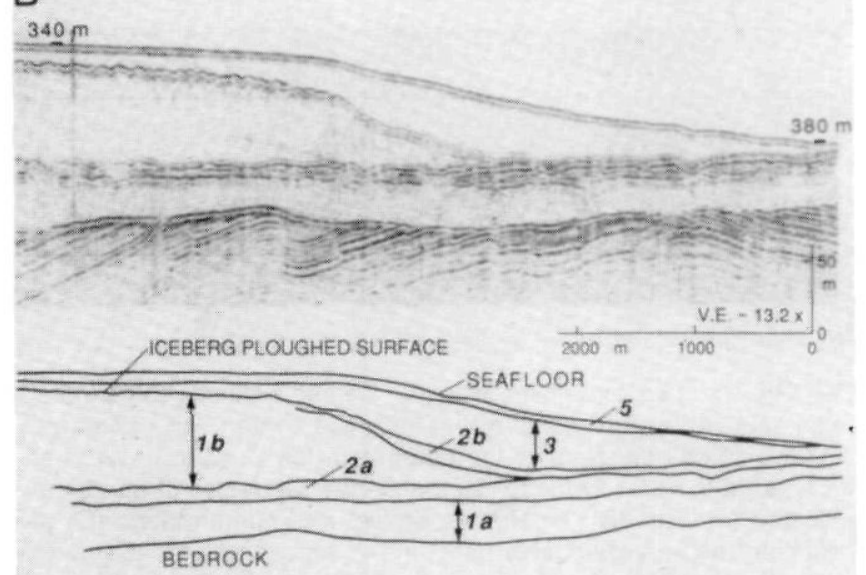

C

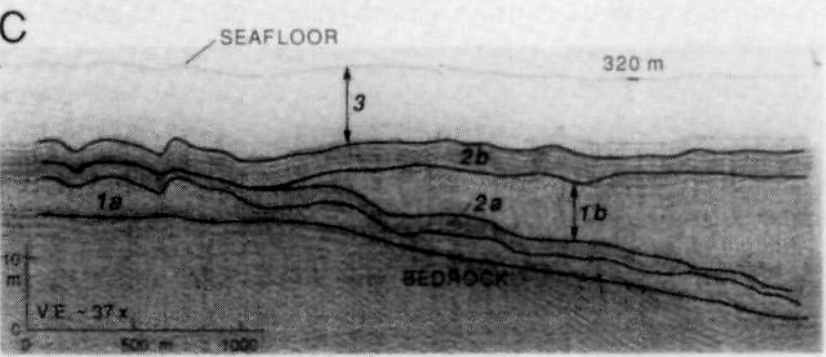

FIGURE 5. Examples of unit 1, Ice Contact Depositional Facies, showing multiple events, possibly from the interaction of two glaciers or from the readvancement of a single glacier (see text for details): A: airgun profile over shallow bank SE of Sept-Illes; B: airgun profile over south shore of Laurentian Trough near Gaspé; C: Huntec profile of north shore of the Laurentian Trough, east of Pointe-des-Monts. Note the two distinct ice contact and ice proximal units in both (B) and $(\mathrm{C})$.

Exemples prélevés dans l'unité 1. Faciès sédimentaire de contact glaciaire révélant l'existence d'épisodes multiples découlant soit de l'interaction de deux glaciers, soit de la récurrence d'un glacier unique (voir le texte pour plus de détails): A: profil obtenu par fusil à air comprimé au-dessus d'un banc peu profond, au sud-est de Sept-llles; B: profil obtenu par fusil à air comprimé au-dessus de la rive sud du chenal laurentien, près de Gaspé: C: profil de la rive nord du chenal laurentien, à l'est de Pointe-des-Monts, obtenu par dispositif Huntec. À noter les deux unités distinctes de sédiments de contact et de sédiments proximaux en $B$ et en $C$.

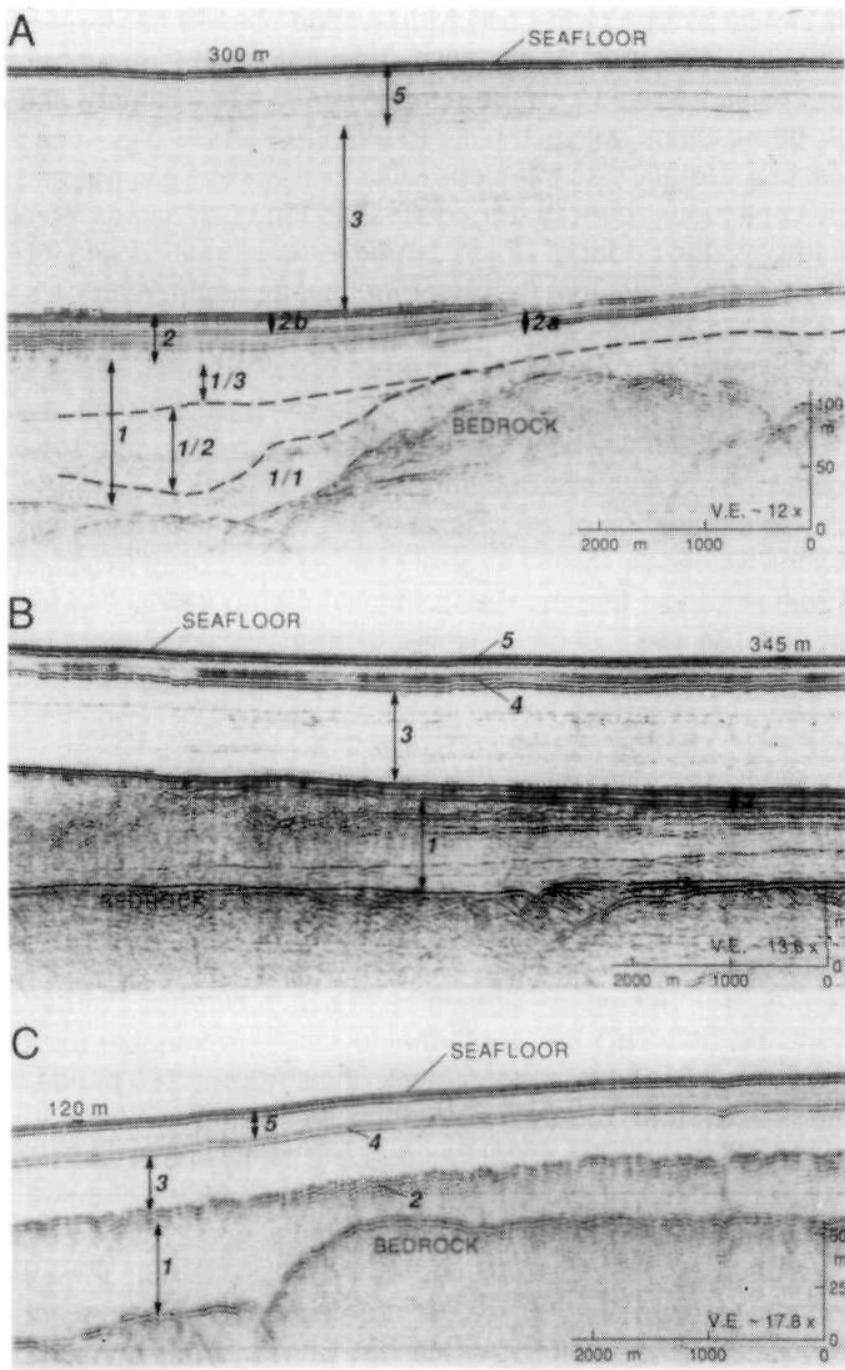

FIGURE 6. Three airgun profiles of the Ice Loaded facies of unit 1: A: profile collected northwest of Rimouski, showing deglacial units of pre-Late Wisconsinan sediment within unit 1; B: profile collected in deep Trough off of the Manicouagan Delta showing developed stratification within unit 1 , and $\mathrm{C}$ : more typical acoustic characteristics of the ice loaded facies of unit 1 , collected along the Trough slope off the Manicouagan Delta, showing no internal stratification. Also note in $(B)$ the two distinct intervals within unit 2 , denoting the retreat phase (unit 2a) and sedimentation from the ice terminus still stand at the head of the estuary (unit $2 b$ ).

Trois profils obtenus par fusil à air comprimé, illustrant le faciès de sédiments comprimés par le glacier dans l'unité 1: A: profil réalisé au nord-ouest de Rimouski, montrant des sédiments d'âge préwisconsinien supérieur; $B$ : profil réalisé dans le profond chenal au large du delta de la rivière Manicouagan, révélant une stratification développée; $C$ : profil plus typique du faciès de sédiments comprimés par le glacier, réalisé le long de la pente du chenal prolongeant le delta de la rivière Manicouagan et ne présentant aucune stratification interne. A noter aussi en B, dans l'unité 2, les deux intervalles distincts dénotant la phase de retrait (unité $2 a$ ) et la sédimentation conséquente à la fusion du front glaciaire stable en amont de l'estuaire (unité $2 b)$. 
is similar to that of the overlying wedge-shaped deposits of the Late Wisconsinan deglacial sediments (unit 2 through 5) in this same region. In the deeper parts of the Estuary and in depressions within the surrounding shelves, unit 1 can contain laterally discontinuous reflectors, or can be separated by continuous reflectors or contrasting tone into two or more intervals, the upper of which can be locally stratified (Fig. 6b $\& c)$. We suggest that these sub-units may relate to an early deglacial sequence, conceivably with a lower unit of ice contact deposits (unit 1/1 on Fig. 6c), overlain by ice proximal deposits (unit 1/2) and finally ice distal deposits (unit 1/3). As the surface of unit 1 would have been loaded by the Late Wisconsinan ice advance, the surface relief of unit 1 may reflect the sole markings of the glacier - similar to those observed for the historically recent surge of Bråsvellbreen, off of Svalbard (Solheim and Pfirman, 1985). Finally, the bounding surface of unit 1 in the Trough is similar in shape to what might be expected for the bottom profile of a confined ice stream.

\section{ICE PROXIMAL SEDIMENTS: UNIT 2}

Unit 2 is typically characterized by strong, closely spaced reflectors. It may occur as (e.g. Fig. 7a): (i) a facies that is conformable with unit 1 or bedrock, and relatively thin, and (ii) a wedge-shaped facies containing ponded sequences and slump deposits and directly related to known ice marginal still stands. Both facies are present in the St. Lawrence Estuary (Figs. $6 \mathrm{c}$ and $7 \mathrm{a}$ ): the conformable facies is variably thick $(<20 \mathrm{~m})$, the wedge-shaped facies thins from $\approx 160 \mathrm{~m}$ near the head of the Trough to zero at its limit $40 \mathrm{~km}$ seaward. In the NW Gulf, unit 2 is not ubiquitous and its thickness seldom exceeds $10 \mathrm{~m}$. Where present, the two type facies of unit 2 do not appear in combination. For example, unit 2 may drape over bedrock (Fig. 7b and 7c), or unit 1 (Figs. 3a,5c), or may form a wedged-shaped facies interfingering with morainal deposits (Figs. 4 and 5B). In Baie des Chaleurs, glaciomarine deposits vary laterally from conformable to ponded sequences: units 2 and 3 are difficult to differentiate.

On the basis of cored sediments from the glacial-influenced fjords of Baffin Island which have similar acoustic attributes (Syvitski and Farrow, 1989; Syvitski, 1989), we interpret these sediments as alternating beds of sand and mud. We relate unit 2 to ice proximal sedimentation associated with high rates of deposition of relatively coarse particles close to a major discharge outlet along the face of a glacier. The discharge outlet may originate at the base of the ice sheet (subglacial), or any position above (englacial and supraglacial). Syvitski (1989) demonstrated that glaciofluvial discharge into seawater occurs normally as a buoyant jet and plume. Thus sedimentation at the face of a tidewater ice sheet may locally be considered 'ice distal' as long as its position is at a significant distance away from a discharge outlet.

The conformable facies of unit 2 relates to sedimentation associated with a rapidly retreating ice margin. Syvitski (1989) demonstrated that for an unstable ice margin, glaciomarine accumulation is largely controlled by the rate of ice terminus retreat. During a rapid retreat phase, there would be no opportunities to build a large ice contact fan or frontal dump moraine where slumps and turbidity currents could be gen-

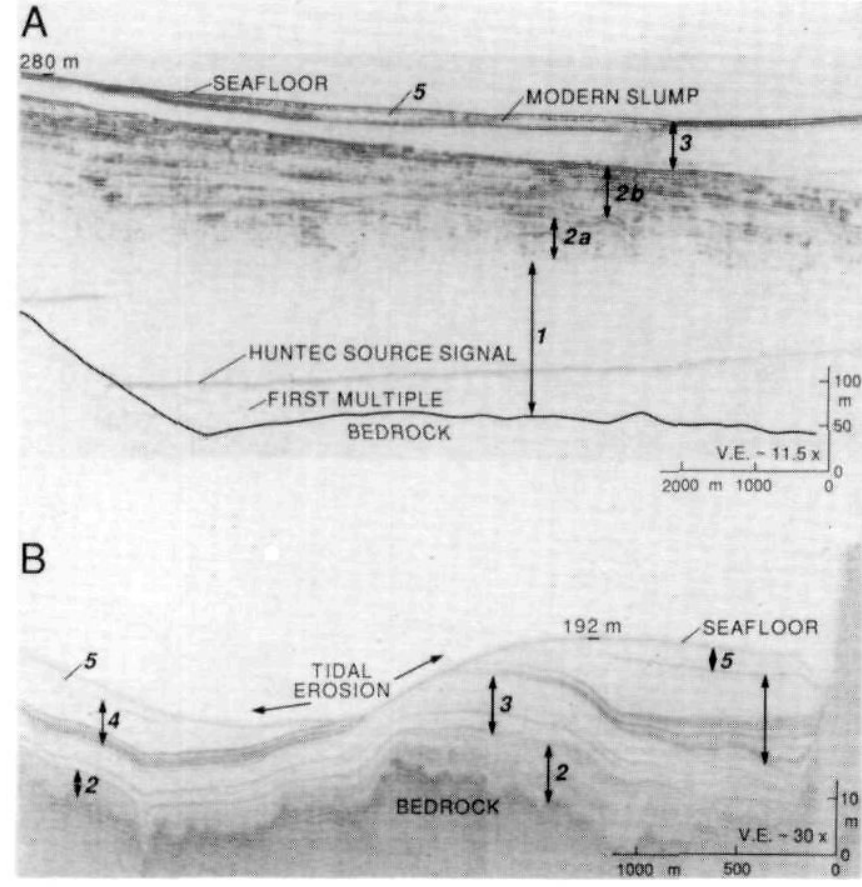

FIGURE 7. Two examples of unit 2, coarse-grained ice proximal sediments: A: airgun profile of the large ice contact fan generated from the $13 \mathrm{ka}$ still stand of the Laurentian Ice Conduit, located at the head fo the St. Lawrence Estuary - the two facies of unit 2 are indicated (cf. Fig. 6B); B: Huntec profile, and interpretation (C) of the conformable yet variably-thick unit 2 deposited near the north shore of the NW Gulf of St. Lawrence. Note the non-deposition or erosion of units 4 and 5 and only minor erosion of unit 3 , the cohesive ice distal clays.

Deux exemples prélevés dans l'unité 2 composée de sédiments proximaux grossiers: A: profil, obtenu par fusil à air comprimé, du vaste cône de contact glaciaire engendré par l'arrêt du glacier laurentien situé en amont de l'estuaire du Saint-Laurent (les deux faciès de l'unité 2 sont indiqués à la figure 6B); B: profil obtenu par dispositif Huntec et interprétation des sédiments concordants mais d'épaisseur variable de l'unité, déposés près de la rive nord, dans le nord-ouest du golfe du Saint-Laurent À noter l'absence de sédimentation ou l'érosion des unités 4 et 5 , ainsi que la faible érosion des argiles distales cohérentes de l'unité 3.

erated. Significant areas of the NW Gulf only contain a thin layer of facies 2 and may have experienced ice proximal sedimentation for only a short period during a rapid retreat phase. The discontinuous distribution of unit 2 in the NW Gulf may imply large distances between ice-front discharge outlets, or alternatively, variations in the rate of retreat - a factor very much dependent on the calving rate and thus water depth (i.e. as constrained by sea level fluctuations and bathymetry). Thus the wedge-shape configuration of unit 2 in Figure $7 \mathrm{~b}$ may relate to the slowing of the ice front retreat rate over an offshore bank and not necessarily to an ice front still stand.

The more striking wedge-shaped deposits reflect the recognized exponential decrease in the rates of sedimentation out from a stable ice marginal position (Syvitski, 1989). Similarily, the closely-spaced reflectors, the slump features and the generation of ponded sequences (i.e. turbidites) all support the notion of an ice terminal still stand. Turbidity currents 
associated with ice-front slumping would more effectively spread sand and mud out from the ice margin, as surface plumes lose the sand fraction close to the ice margin (Syvitski, 1989). The distribution of unit 2 within the Laurentian Trough suggests that the major source of sediment is a $13 \mathrm{ka}$ ice margin still stand, near the head of the Trough (cf. Dyke and Prest, 1987).

The bounding surfaces of units 1 and 2 show evidence of scouring by the keels of icebergs - bergs rather than sea ice because of the 100 to $300 \mathrm{~m}$ water depth in which they are presently found (i.e. paleo depths of 200 to $400 \mathrm{~m}$ ). These iceberg scours are recognized by characteristic hyperbolics on acoustic profiles indicating a surface roughness up to $5 \mathrm{~m}$ in depth and variable width $(<100 \mathrm{~m})$. Although mostly buried below units 3 through 5 , units 1 and 2 are exposed on shallow banks in the NW Gulf and Baie des Chaleurs. Sidescan sonar records show a curvilinear and intersecting pattern of icescours (cf. Syvitski et al., 1983b). These ice scours represent paleo ice-scouring generated from icebergs calved from the Laurentide Ice Sheet.

\section{ICE DISTAL SEDIMENTS: UNIT 3}

Unit 3 is typically characterized by distinctive very low tone, weak stratification, and a conformable bedding style in which basal topography underlying the unit is translated through internal reflectors to the surface (Fig. 9). The unit can be traced up to, and correlated with, the extensive marine clays along the shores of the St. Lawrence Estuary and Gulf, mapped as Leda Clay, Mer de Laflamme Clay, and Goldthwait Sea clays (e.g. Dredge, 1983; Locat et al., 1984). These sediments consist of distinctive blue-grey, stiff, massive to laminated clays, and can exceed $230 \mathrm{~m}$ in thickness (e.g. Moisie River Valley: Dredge, 1983). The subaerially exposed clays were deposited into a coastal sea (named the Goldthwait Sea) between 14 to $10 \mathrm{ka} \mathrm{BP}$ (Locat et al., 1984). At that time the sea was much larger than the modern St. Lawrence Seaway, being some 100 to $200 \mathrm{~m}$ above present shorelines. Many of the terrestrial deposits are "quick" and fail under stress. The marine extension of unit 3 has been sampled through conventional coring (e.g. d'Anglejan and Brisebois, 1974; Loring and Nota, 1973, as well as during our surveys).

Unit 3 represents ice distal accumulation of glaciomarine sediment in the Goldthwait Sea from glaciofluvial plumes discharged from the Laurentide Ice Sheet. The unit is thus intimately linked to the ice proximal unit 2 (e.g. in Fig. 7 unit 2 laterally grades into unit 3), although the sedimentation occurring at any one location could involve sediment from a number of discharge plumes that together form the buoyant surface layer within the glacial sea. According to the data of Görlich et al. (1987) and hydrodynamics described by Syvitski (1989), unit 3 would represent sediment deposited outside the influence of the submarine discharge jet. The conformable or draped bedding style (e.g. Figs. 7, 9a and 9b) suggests relatively low bottom currents. However, unit 3 may locally offlap (Fig. 7a) or even be absent over bedrock highs, which suggests that bottom currents influenced the sediment distribution in some areas.
Unit 3 reaches maximum thicknesses of at least $290 \mathrm{~m}$ in parts of the North Channel (Charlevoix region), up to $500 \mathrm{~m}$ in the Saguenay Fjord, and $167 \mathrm{~m}$ within the Laurentian Trough off Rimouski. The unit is absent at the entrance to the Saguenay. The unit is difficult to constrain in the NW Gulf where it grades vertically into Holocene mud of unit 5 . Regional variations in thickness are interpreted to reflect distances from the many possible sediment sources both axial and marginal to the St. Lawrence system, and the general circulation of the buoyant surface plume. This is illustrated by the depositional thalweg in the Laurentian Trough, which hangs to the south side of the Trough. This is similar to modern conditions, whereby sediment plumes hang to the south side of the St. Lawrence Estuary under the influence of Coriolis Force (Mertz et al., 1988).

Marginal sources for unit 3 are observed along the north and south shores of the lower Estuary indicated by intervals of strong internal stratification, that grade distally into typically weak stratification. On the north shore these intervals take the form of conformably stratified sediment, grading laterally into ponded lobes similar in bedding style and geometry to the sandy paraglacial deltaic lobes of unit 4 (Fig. 8a). The lobes occur along the north shore at varying stratigraphic levels within unit 3. On the south shore of the lower Estuary intervals of stronger stratification at two stratigraphic levels can be traced along the shore for $80 \mathrm{~km}$. These intervals can smooth out basal relief, and locally contain channels or channelfill. The persistence of these intervals over a large area suggests cycles of coarser sediment supply from the Gaspé shore.

Unit 3 has been locally affected by sediment failure and mass flow transport. Large scale failure is observed in three places along the south side of the lower St. Lawrence Estuary. The largest is $>30 \mathrm{~km}^{2}$ in areal extent and is located on the slope off Rimouski. On the floor of the trough adjacent to the steep southern wall the failure zone displays a loss of stratification in association with a crenulated surface and increased thickness, which are acoustic characteristics of debris flows in the marine environment (Syvitski et al., 1987b). On the adjacent shelf, unit 3 contains failure scarps up to $30 \mathrm{~m}$ deep and associated with large listric faults (Fig. 8b).

Seabed erosion of unit 3 has occurred over a large area in the North Channel, which is strongly influenced by currents. The associated surface unconformity appears as a distinct sidescan image of low relief and narrow lineations which represent truncated bedding planes of unit 3 . Similar features were observed visually through shallow water off the Manicouagan delta during our nearshore launch surveys (B.F. Long, pers comm, 1988) and offshore of Sept-îles (Fig. 7b). An angular unconformity across this unit was also observed in parts of Baie des Chaleurs (e.g. Fig. 11c) - associated with erosion during lower sea levels of the early Holocene (C.T. Schafer, personal communication, 1988).

\section{PARAGLACIAL DELTAIC SEDIMENTS: UNIT 4}

The paraglacial cycle was first defined by Church and Ryder (1972) and later expanded for marine sedimentation by Syvitski et al. (1987b). Paraglacial sedimentation refers 

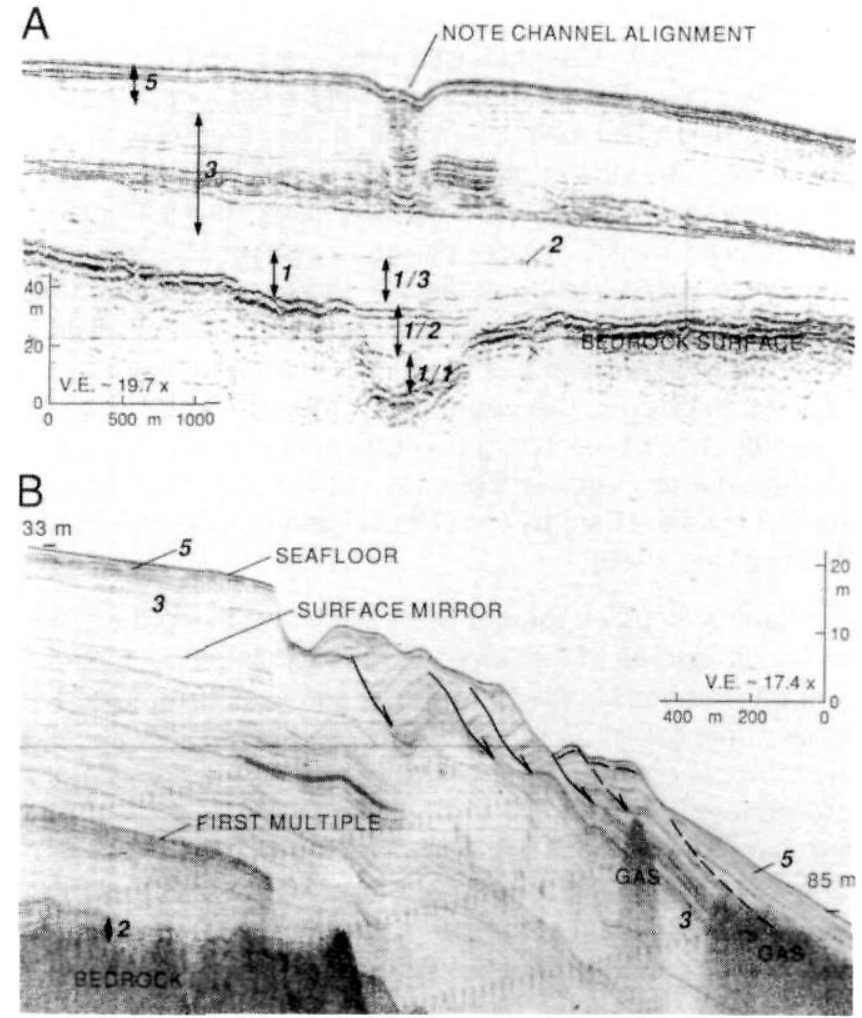

FIGURE 8. Two examples of unit 3, denoting fine-grained ice-distal sediments: A: airgun profile of the Rivière Betsiamites, unit 3 shows the typical low tone and conformable nature. However in this example, it contains an interval of deltaic sedimentation (unit 4), interpreted to indicate that a portion of the ice terminus is both on land and in the ocean. Also note the juxtaposition of the modern submarine valley, the paraglacial valley, the fan sandwiched in unit 3 , and possibly Tertiary valley cut into bedrock - indicating a consistent drainage pattern maintained over a long period of time; B: Huntec profile collected just north of Rimouski, this profile shows one of the few examples of submarine failure of unit 3 . Also compare the increased stratification within this profile as compared to (A).

Deux exemples prélevés dans les sédiments distaux fins de l'unité 3: A: profil obtenu par fusil à air comprimé au large de la rivière Betsiamites et illustrant la faible tonalité et la nature concordante de l'unité 3. Cet exemple renferme cependant un intervalle de sédimentation deltaïque (unité 4) qui semblerait indiquer qu'une portion du front glaciaire se trouvait à la fois sur le continent et dans la mer. A noter aussi la juxtaposition de la vallée sous-marine actuelle, de la vallée paraglaciaire, du cône intercalé dans l'unité 3 et de la vallée vraisemblablement d'âge tertiaire encaissée dans la roche en place, révélant la longue existence d'un réseau hydrographique. B: Profil obtenu au nord de Rimouski par dispositif Huntec et représentant, dans l'unité 3 , un rare exemple de glissement sousmarin. A comparer la stratification de ce profil à celle illustrée en A.

to the abnormally high transport of sediment from land to the sea via fluvial discharge from a terrestrial ice sheet that is experiencing rapid ablation. Vast quantities of glacial, proglacial and exposed marine terrace sediments are available for fluvial erosion and transport, and thus account for abnormally high rates of denudation. Generally this type of sedimentation occurs within the Hypsithermal period which for the Gulf of St. Lawrence happened between 13 to $8 \mathrm{ka}$ BP. It was a time of warm, dry summers associated with fluvial discharge over an order-of-magnitude greater than is presently found for these rivers (Church and Ryder, 1972). We therefore refer to unit 4 as the paraglacial deltaic unit both to emphasize a specific geologic period and to differentiate the deltaic unit from those forming today (see below) through fluvial cannibalism of raised marine terraces of units 3 and 4 .

Unit 4 is characterized by strong and dense acoustic stratification and generally ponded bedding style (Fig. 9a) although the unit may distally be conformable over unit 3 (right portion of Fig. 9c) and laterally grade into unit 5. The unit commonly contains unstratified lobes representing syn-depositional mass flows, as well as buried channels and shear planes related to submarine slides (Fig. 9). Unit 4 occurs along the north shore of the Gulf of St. Lawrence and the Laurentian Trough, where it forms progradational wedge-shaped lobes up to $100 \mathrm{~m}$ thick. These lobes are directly related to the position of modern north shore deltas, although deposits of unit 4 are almost an order-of-magnitude larger than the postglacial deposits (unit 5) related to these deltas (Fig. 9). Dredge (1983) has mapped the terrestrial equivalent of unit 4 as part of a marine offlap sequence that can be traced as "extensive coalescing deltas where meltwaters emptied into the Goldthwait Sea". Her equivalent deposits include littoral topset beds overlying nearshore foreset deposits.

P. Carison and R. Powell (pers. commun., Feb. 1988) have noted that in Glacier Bay Alaska, marine basins with tidewater glaciers in active retreat do not contain large submarine channels, usually formed through erosion by turbidity currents. However, where trunk glaciers have retreated to terrestrial positions, large deltas have been formed. More importantly, submarine channels are intimately associated with the progradation of these glacier-influenced deltas, a result of delta front instabilities and foreset failure. This observation is further supported by data on submarine channels within Baffin Island fjords (Syvitski and Farrow, 1989). Submarine channels are capable of focusing coarse-grained bedload into offshore basins after bypassing significant portions of the proximal prodelta environment (Schafer et al., 1989) : the hydrodynamics of this process are described by Syvitski et al. (1988). As a result, unit 4 represents coarse sediment transported offshore via slumps, slides and turbidity currents, that overlie the finergrained ice-distal sediments of unit 3 (e.g. Figs. $6 a$ and $6 \mathrm{~b}$, 9a and 9c, 10).

\section{POSTGLACIAL SEDIMENTS: UNIT 5}

The uppermost Quaternary unit 5 forms the seabed almost everywhere and reflects the establishment of modern (postglacial) sedimentation patterns concomittant with a lowered sea level and ablated Late Wisconsinan ice sheets. No dates have yet been obtained on the transition from unit 4 to unit 5. We speculate that the transition occurred between 8 to 6 ka after which modern marine conditions were established with only minor fluctuations in sea level (Dionne, 1988). Unit 5 occurs in two main acoustic styles or facies: deep-water basinal muds and shallow-water sand and/or gravel lags.

\section{Basinal Mud Facies}

This facies is typically characterized by low tone, weak reflectors, some of which are gas horizons, and a basinal 

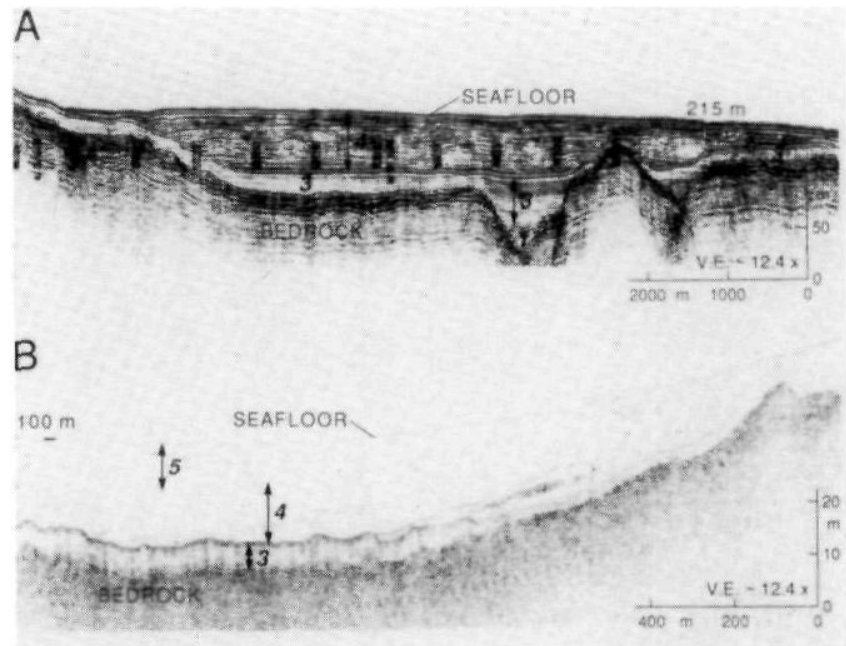

C
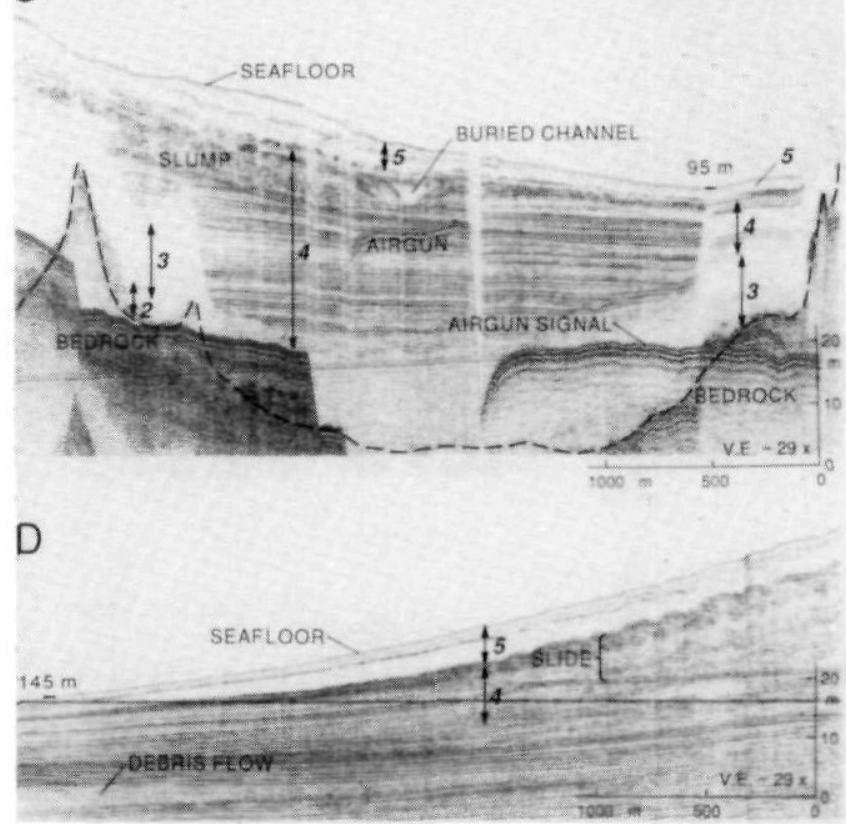

FIGURE 9. Four examples of the Paraglacial Deltaic unit 4: A airgun profile near the Rivière Sainte-Marguerite, Sept-îles, showing the classical ponding and chaotic bedding style of sediments deposited from mass flow mechanisms including turbidity currents and debris flows; B: Huntec profile of overlapping sequence of unit 4 in Baie des Chaleurs; C: Huntec profile of Paraglacial Deltaic filling of offshore bathymetric irregularities near Rivière Moisie; $D$ : Huntec profile of alternating slumps and turbidities within unit 4 , collected seaward of the Riviere Moisie, showing subsequent failure of the uppermost portion of the sequence.

Quatre exemples prélevés dans les sédiments deltaïques paraglaciaires de l'unité 4: A: profil obtenu par fusil à air comprimé près de la rivière Sainte-Marguerite, à Sept-illes, et représentant la stratification irrégulière des sédiments mis en place sous l'influence de mécanismes comme les courants de turbidité et les coulées de débris; B: profil d'une séquence en retrait, obtenu dans la baie des Chaleurs par dispositif Huntec; C: profil des sédiments deltaïques paraglaciaires comblant les irrégularités du fond, obtenu par dispositif Huntec au large de la rivière Moisie; D: profil obtenu par dispositif Huntec au large de la rivière Moisie; il représente les successions de dépôts issus de glissements et de courants de turbidité et illustre le décrochement subséquent de la portion supérieure de la séquence.
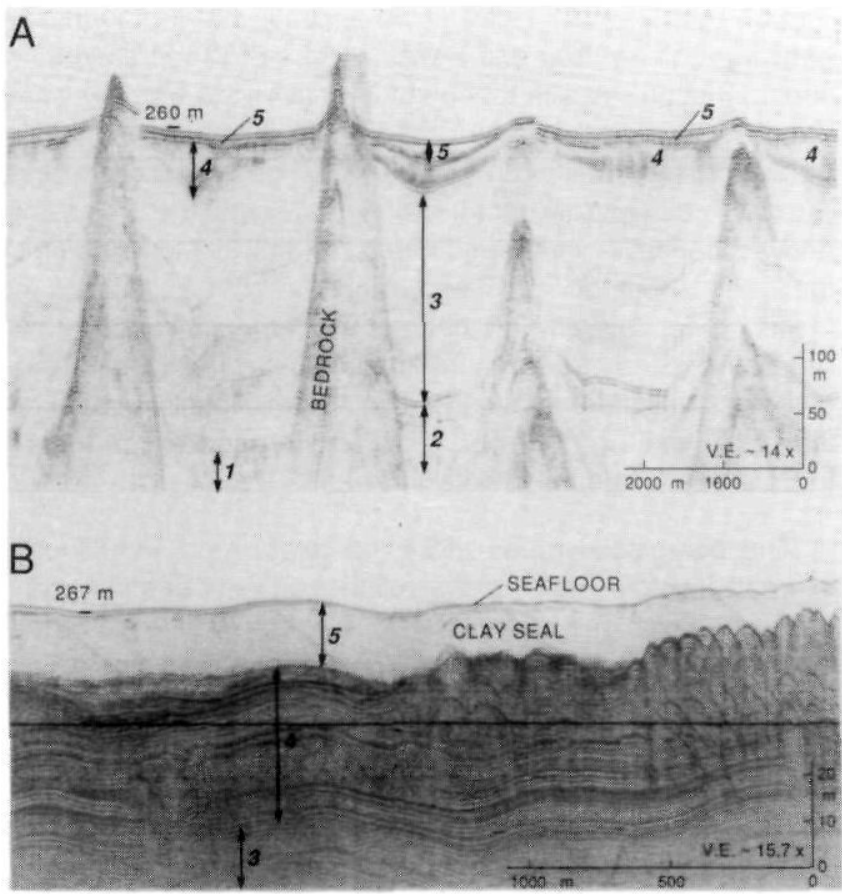

FIGURE 10. Examples of the world's largest internal slump within the paraglacial deltaic sediments of the lower portion of the Saguenay Fjord: A: airgun record of three traverses of the fjord, showing variable failure within the unit; B: Huntec record shows the complexity of failure within unit 4 and the overlying clay of unit 5 .

Dans les sédiments deltaïques paraglaciaires du cours inférieur du Saguenay, exemples du plus grand glissement sous-marin jamais observé: A: trois profils transversaux obtenus dans le Saguenay par fusil à air comprimé et montrant des décrochements variables; B: profil obtenu par dispositif Huntec et illustrant la complexité des décrochements dans les sédiments de l'unité 4 et dans les argiles de l'unité 5 qui les recouvrent.

geometry which smooths or masks basal relief. These acoustic attributes together with core information indicate a muddy, organic-rich facies that corresponds to pelites of Loring and Nota (1973). The unit marks the period when glacial meltwater no longer drained into the Seaway, when terrestrial vegetation was established, and mud deposition was confined to deep or protected waters and not subjected to modern tidal or wave action.

The thicknesses and lateral distribution of this subunit reflect the influence of modern sources and circulation patterns. In the Saguenay Fjord, unit 5 thins seaward from $100 \mathrm{~m}$ at the head of the fjord to $<10 \mathrm{~m}$ in the distal parts of the basin: a pattern that is reflected in measured rates of accumulation (Smith and Walton, 1980). In deeper parts of the Upper St. Lawrence, unit 5 can reach $30 \mathrm{~m}$. Near the head of the Laurentian Trough is a zone of nondeposition in an area of tidal upwelling (upward vertical velocities of $35 \mathrm{~m} \mathrm{~h}^{-1}$ ) and mixing (Gratton et al., 1988). The mud facies of unit 5 occurs as a widespread cover on the floor and walls of the Laurentian Trough, with a unit thickness of $60 \mathrm{~m}$ near the head of the trough and thinning seaward along the southern margin to $<15 \mathrm{~m}$ at the entrance to NW Gulf. The depositional thalweg reflects the established Gaspé current - a buoyancy-driven coastal jet that hugs the southern margin of the Estuary and 
Trough (Mertz et al., 1988). If we assume that the boundary between unit $3 / 4$ and unit 5 was at $8 \mathrm{ka} \mathrm{BP}$, then maximum sedimentation rates in the lower St. Lawrence Estuary were $7.5 \mathrm{~m} / 1000 \mathrm{yr}$ or $\approx 1 \mathrm{~cm} / \mathrm{yr}$. The postglacial muds remain thin throughout most of the NW Gulf basin, although exact thickness is difficult to constrain because unit grades into the underlying and acoustically similar sediments of unit 3 . Along parts of the north shore of the Estuary and the NW Gulf, the mud facies grades laterally into coarser modern deltaic sediments (Fig. 9D) exceeding $30 \mathrm{~m}$ in thickness. South of Anticosti Island, postglacial sediments become thin and are locally absent on the south wall of the Trough, but thicken and exceed $25 \mathrm{~m}$ in Baie des Chaleurs (Syvitski et al., 1987a).

The postglacial muds are often associated with strong internal reflectors (Fig. 11d) that relate to acoustic enhancement associated with gas, and in some cases possibly to ice-rafted boulders. Unit 5 sediments may contain gas horizons which partly or completely mask the underlying section (e.g. Baie des Chaleurs: Syvitski et al., 1987a). Generally these horizons are located at a consistent depth a few metres below the seabed. Often the gas horizons are associated with 'gasescape' seabed depressions, which in Baie des Chaleurs appear as linear features on sidescan images (Fig. 11c; Syvitski et al., 1983a). Gas reflectors are commonly reported from thick estuarine or marine muds, and reflect concentrated gas generated from the decay of organic matter (Keen and Piper, 1976). Gas may also rise to the seabed through the Quaternary section from the underlying bedrock, and sources of natural gas are known in the St. Lawrence area. Gas horizons were not observed in Quaternary units underlying unit 5.

Point-source reflectors are present within unit 5 in variable proportions on Huntec records from the Lower Estuary. These occur at different levels within the sediments, but in some parts of the Estuary are more common at a consistent level that grades laterally into gas horizons discussed above. It is possible the point-source reflectors indicate the presence of boulders larger than the horizontal limits of resolution of the Huntec system (1-2 m). Sea ice-rafting of boulders has been proposed as an important modern depositional mechanism for the St. Lawrence Estuary by Dionne (1972). However the lateral gradation into more continuous gas reflectors may indicate that these features are a result of intermittent gas pockets larger than 1-2 $\mathrm{m}$. Both gas escape features and large ice-rafted boulders have been observed from submersible dives within the Estuary (Syvitski et al., 1983a).

Mass displacement of the postglacial muds occurs in both the St. Lawrence Estuary and the Saguenay Fjord, but is rare in the NW Gulf. The pattern of displacement may reflect the proximity to the seismically-dynamic Charlevoix zone, where horizontal accelerations of $>0.3 \mathrm{~g}$ have been recorded (Earth Physics Branch data, D.E.M.R. Canada). At the head of the Laurentian Channel in the lower Estuary displaced lobes from both the north and south walls are observed, with acoustic characteristics indicating a suite of mass flow styles from slides to distal debris flows (Nardin et al., 1979). In the North Channel, nearest the Charlevoix epicentres, mass displacement by slides is indicated along most of the steep north wall
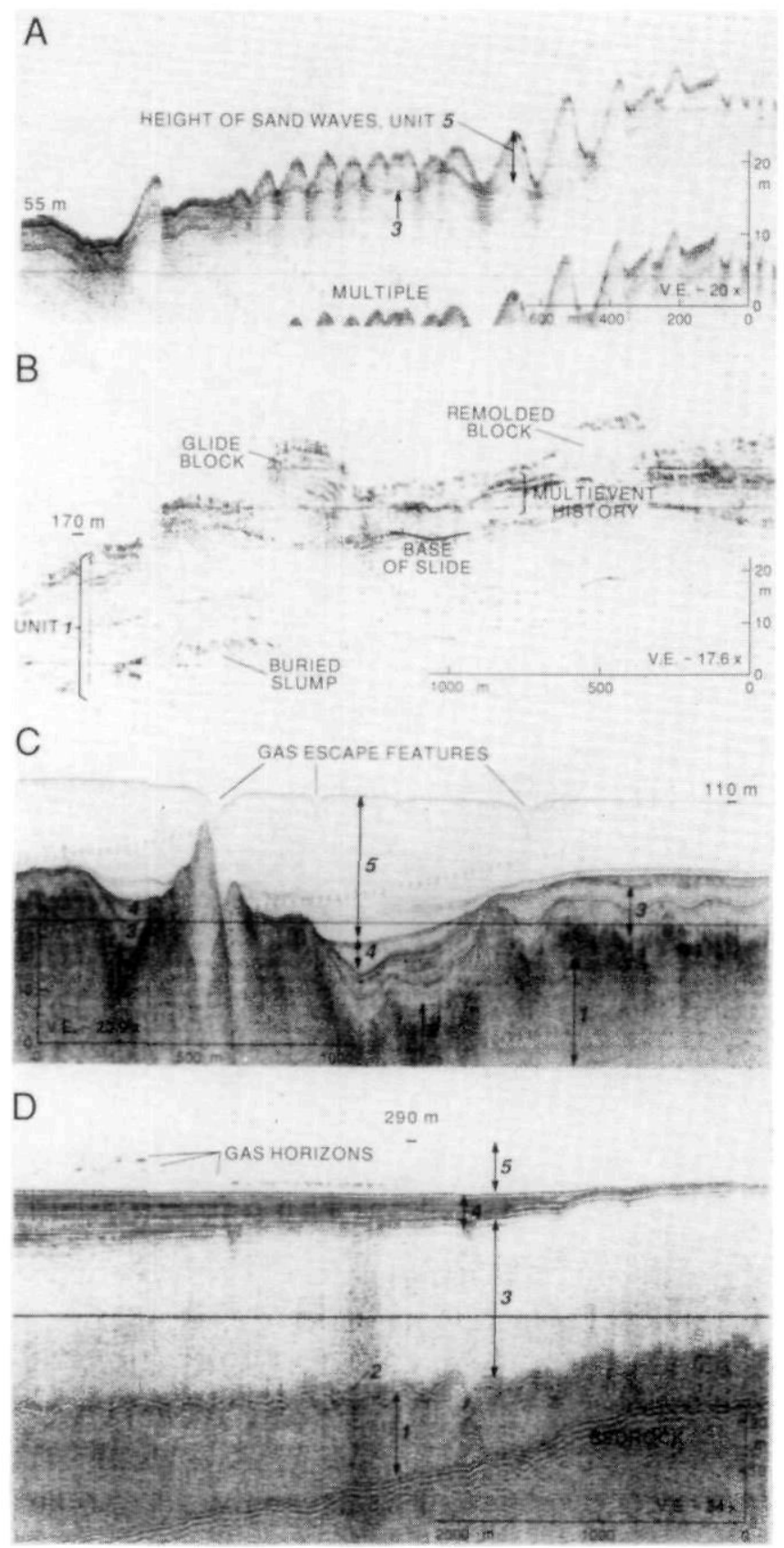

FIGURE 11. Huntec profiles demonstrating the complexity and variability of unit 5 , postglacial deposits: $A$ : sand waves within the North Channel; B: coherent and remoulded slump blocks near the head of the Saguenay Fjord; C: gas-charged sediments showing gas-escape features at the seafloor in Baie des Chaleurs. Note the internal erosional surface marking a period of increased current activity and lowered sea levels; D: gas-charged sediments showing masking at three levels within unit 5 .

Profils obtenus par dispositif Huntec, révélant la complexité et la diversité des sédiments postglaciaires de l'unité 5: A: vagues de sable dans le chenal nord; B: à l'amont du Saguenay, glissements massifs et remaniés; $C$ : dans le fond de la baie des Chaleurs, sédiments gazifères présentant un relief caractéristique de libération des gaz. A noter la surface d'érosion qui révèle une période marquée par une intensification de l'activité des courants et un abaissement du niveau de la mer; $D$ : sédiments gazifères masquant trois niveaux de l'unité 5. 
of the Estuary. One large earthquake took place in the winter of 1663 and may have reached Richter 8 magnitude: in the Saguenay Fiord over $3 \mathrm{~km}^{3}$ of marine sediment was displaced. As a consequence, slide blocks up to $30 \mathrm{~m}$ high are found scattered along the basin floor (Fig. 11b).

\section{Sand and Gravel Lags}

In shallower water surrounding the basinal muds, the seabed is composed of coarse lags developed on older Quaternary units or bedrock. Generally these lags are thin $(<1 \mathrm{~m})$ and not resolvable on seismic reflection records. They are recognized through sampling and on sidescan sonar records as gravel lags with sand lineations or patches. Thicker accumulations of sand can be found locally, usually in association with bedforms. This facies of unit 5 is correlative to the sand and gravel deposits recognized by Loring and Nota (1973) in the Lower Estuary and the NW Gulf, and by d'Anglejan and Brisebois (1978) in the Upper Estuary. These lags are thought to reflect increased postglacial current erosion in shallower water levels since the time of the Goldthwait Sea maximum.

In the upper North Channel at the edge of our study area, sand waves $>8 \mathrm{~m}$ in height are observed in an area where currents exceed $3.5 \mathrm{~m} \mathrm{~s}^{-1}$ (Fig. 11a). Lags are present over most of the floor of the upper Estuary southwest to Québec City (D'Anglejan and Brisebois, 1978). They generally occur above depths of $50 \mathrm{~m}$, and include sediments in both basins and banks. At the entrance and in the mouth of the Saguenay Fiord, sandy bedforms are common above depths of $50 \mathrm{~m}$ but can be found in waters as deep as 150 m over sills where currents exceed $2 \mathrm{~m} \mathrm{~s}^{-1}$. In the lower Estuary lags occur along the southern shelf in water $<30 \mathrm{~m}$, and locally as small banks along the northern shelf ( $<70 \mathrm{~m}$ at Pointe-des-Monts; Syvitski et al., 1983a).

In outer Baie des Chaleurs, sands and gravels are observed along the margins of the bay above a water depth of $30 \mathrm{~m}$, and some seismic profiles show that they form an interval several metres thick which extends beneath basinal muds offshore and towards modern beach deposits shoreward. A lowered relative sea level is also indicated in the upper bay where submerged paleo-shorelines above depths of $30 \mathrm{~m}$ are presently buried beneath an extensive veneer of mud (Syvitski et al., 1987a). Changing sea levels and oceanographic conditions in Baie des Chaleurs are further documented (Fig. 11c) in a sequence of acoustic units that demonstrate: (i) increased wave action through onlapping basin fill, the sediment source being from erosion of the shallows; followed by (ii) ponded basin fill, probably associated with increased tidal action; and finally (iii) conformable basin sedimentation reflecting deeper water and lowered current velocities.

\section{TYPE AREAS}

\section{UPPER ST. LAWRENCE ESTUARY}

The North Channel represents the infilled extension of the Laurentian Trough upstream of the entrance to the Saguenay. The Quaternary section is $>350 \mathrm{~m}$ thick and dominated by unit 3 (>290 m): the typical weak stratification and low acoustic tone of unit 3 allows the recognition of bedrock through up to 10 seabed multiples, but the base of the Quaternary section is not continuously observed. Unit 3 is overlain everywhere by up to $30 \mathrm{~m}$ of basinal muds or sand/gravel lags of unit 5 . Basinal muds correspond to sediments above the first regional subbottom reflector of D'Anglejan and Brisebois (1974). The lags occur as a very thin veneer or as large bedforms, often overlying unit 3 in the upper part of the North Channel with a slight angular unconformity. Locally the bedforms cap prograding sand lobes up to $40 \mathrm{~m}$ thick. Sediment slides are observed along the north wall of the North Channel, and in places these have disturbed the basinal muds on the trough floor.

\section{SAGUENAY FJORD}

The Saguenay is truly a wonder of nature and a very unusual fjord. At its deepest, crystalline bedrock is encountered at $1.4 \mathrm{~km}$ below sea level (or up to $1.9 \mathrm{~km}$ using a sound velocity of $2.0 \mathrm{~km} \mathrm{~s}^{-1}$ ), while the surrounding fjord walls are typically $<400 \mathrm{~m}$ above sea level. There are 10 basins within the fjord, divided by bedrock sills between $200 \mathrm{~m}$ and $400 \mathrm{~m}$ in height. The most prominent sills are located at the fjord mouth and near Baie Sainte-Marguerite. Due to a Quaternary fill averaging 700 to $900 \mathrm{~m}$ in thickness (Fig. 12), there are presently only three basins within the fjord. The Quaternary fill exceeds $1.3 \mathrm{~km}$ in thickness just seaward of the Baie Sainte-Marguerite bedrock sill - a likely ice marginal equilibrium position.

Lac Saint-Jean, once joined to the Saguenay during the high sea level stand (Mer de Laflamme), has since been "isolated" and, through advective and diffusive process, transformed into a freshwater basin. However, the sill separating the two basins has effectively trapped the coarsegrained paraglacial sediments (unit 4) transported by the Saguenay River into Lac Saint-Jean. Thus much of the sediment within the upper Saguenay Fjord grades from unit 3 into unit 5 , without an intervening coarse-grained unit 4 . Three hanging valleys in the lower Saguenay Fjord did contribute a $30 \mathrm{~m}$ thick layer of unit 4 that has since been capped by postglacial clays. As a consequence of this clay seal, and historically recent seismic activity, a large internal slump took place (Syvitski, in prep. : Figs. 10a and 10b). The same seismic shock waves failed significant portions of the fjord head and sidewall Holocene sediments (Syvitski and Farrow, 1988; Fig. 11). The present day conditions for marine sedimentation are reviewed by Syvitski et al. (1987b) and Smith and Schafer (1987).

\section{LAURENTIAN TROUGH — LOWER ESTUARY TO NW GULF}

The Laurentian Trough is an overdeepened basin partly filled by a wedge-shaped sediment sequence that thickens from less than $50 \mathrm{~m}$ north of the Gaspé Peninsula to $450 \mathrm{~m}$ in the lower St. Lawrence Estuary (Fig. 12). The Trough is 350 to $400 \mathrm{~m}$ deep north of the Gaspé Peninsula, where it is underlain by sedimentary strata of the Ordovician Platform. The Trough narrows and deepens to over $700 \mathrm{~m}$ between marginal shelves $(<100 \mathrm{~m})$ in the lower Estuary, where it 


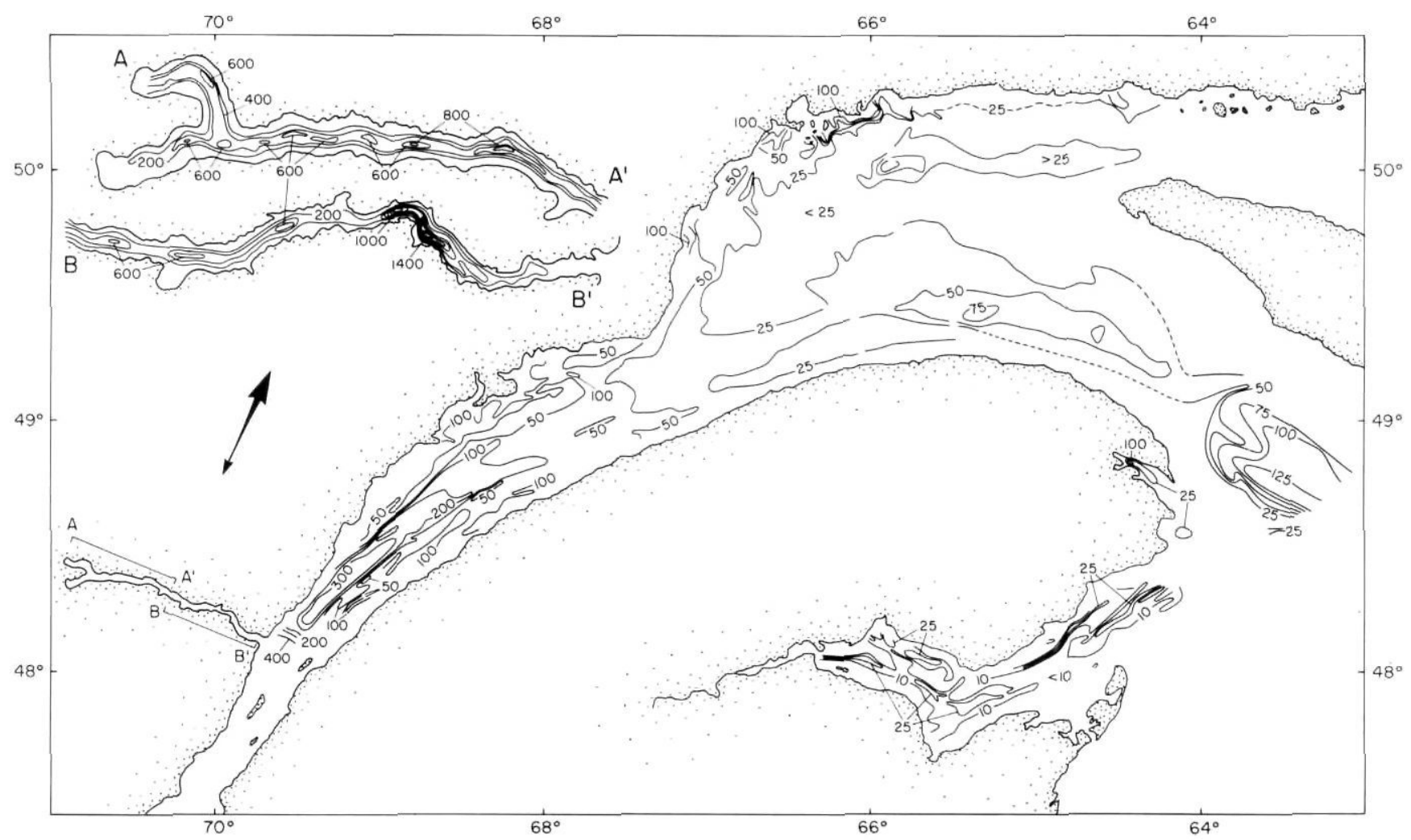

FIGURE 12. Isopach of total Quaternary sediment thickness within the St. Lawrence Estuary and adjacent seas.

straddles the contact between resistant bedrock of the Precambrian Shield to the north and the Appalachian Orogen to the south. A number of broad, low bedrock sills divide the Trough, the largest rising from $700 \mathrm{~m}$ to $500 \mathrm{~m}$ depth at the head of the present Laurentian Trough.

Ice-contact sediments (unit 1) are generally thicker than $10 \mathrm{~m}$, and are $200 \mathrm{~m}$ thick in the deepest parts of the basin. Ice-proximal sediments (unit 2) form a surface drape on unit 1 and are generally less than $10 \mathrm{~m}$ thick, but in the upper $40 \mathrm{~km}$ of the Trough include a prograding wedge up to $250 \mathrm{~m}$ thick at the head of the Trough. The $450 \mathrm{~m}$ accumulation of units 1 and 2 at the present head of the Laurentian Trough is interpreted as a frontal dump moraine/fan complex related to an ice-marginal still stand, probably stabilised by the bedrock sill. The ice-distal sediments of unit 3 are almost ubiquitous in the lower Estuary, with maximum thicknesses of $167 \mathrm{~m}$ along the south side of the deepest part of the trough decreasing exponentially seaward to a limit SW of Anticosti Island. Paraglacial deltaic sediments of unit 4 occur as lobes that extend from the northern shores. The largest, a $90 \mathrm{~m}$ thick lobe, extends into the trough and reflects the paraglacial expansion of the Manicouagan delta system. Postglacial muds are over $60 \mathrm{~m}$ thick on the south side of the deepest part of the Trough. The muds generally thin into shallower water on the walls and the shelves of the Trough, but locally thicken and laterally grade into modern deltaic sediments along the north shore. At the head of the trough and along the southern shelf above 30 to $50 \mathrm{~m}$ depths, and locally on banks on the north shore, the muds grade into sand/gravel lags.
Carte illustrant l'épaisseur totale des sédiments quaternaires dans l'estuaire du Saint-Laurent et dans les régions circumvoisines.

\section{BAIE DES CHALEURS}

The bay is a broad shallow basin, mostly less than $100 \mathrm{~m}$ deep but reaching $150 \mathrm{~m}$ in the outer bay. It is filled with up to $50 \mathrm{~m}$ of Quaternary sediment (Fig. 12). The bedrock consists of sedimentary strata correlative to post-orogenic Carboniferous sediments exposed along the margins of the bay. The bedrock surface contains shore-parallel, generally overdeepened, linear troughs, located on both sides of the bay. In the inner and central bay the southern trough is joined by channels that extend seaward from modern rivers. Unit 1 is generally thin or absent, but in the central and outer bay the bedrock troughs contain linear morainal accumulations up to $30 \mathrm{~m}$ thick, which may reflect the terminal position of the Gaspé ice dome. In the central and outer bay, units $2 / 3$ may reach a similar thickness and are commonly dissected by linear surface features interpreted as relict ice scours. Units $2 / 3$ have been subject to erosion along the margins and toward the inner part of the bay, where the units are observed to thin into shallower water, and their surface unconformities and scour relief are smoothed out. This period of erosion is associated with lowered sea levels, during which terraces and surface lags of unit 5 formed along the margins of the central and outer bay above depths of about $70 \mathrm{~m}$. The inner bay, above depths of about $50 \mathrm{~m}$, has been subaerially exposed and was occupied by a large sandur. The delta was partly fronted by a barrier island formed by reworking of an exposed moraine (Syvitski et al., 1987a). Basinal muds of unit 5 were initially deposited in the deeper waters of the central and outer bay and later, as sea levels rose, formed an extensive veneer across the inner bay. The 
muds show a progression in bedding styles related to the sea level cycle, and in thicker sections (up to $35 \mathrm{~m}$ ) contain prominent gas reflectors.

\section{LATE WISCONSINAN MARINE SEDIMENTATION MODEL}

The Quaternary depositional features outlined above allow us to propose a model of marine sedimentation during the withdrawal of continental ice sheets that we feel can be usefully applied to other glaciated shelves of the world. Obviously not all of our evidence could be presented in an overview manuscript, and forthcoming papers will deal with local details in a more rigorous manner. Below we present our model conceptually through a series of ice stages (Fig. 13) and with associated two-dimensional cross-sections (Fig. 14).

\section{STAGE 1 - INITIAL ICE FRONT ADVANCE}

Whether an advancing ice sheet will override previously deposited marine sediment or erode such sediment down to bedrock will depend on the shear stresses generated from the base of the ice onto the seafloor. These stresses depend on: (i) the topographic gradients (regional and local) that the ice sheet is required to flow over, (ii) the mass of the ice in the marine environment (i.e. the thickness and effective density of the ice in the water column), (iii) ice surface gradients, and (iv) the properties of the seafloor substrate, including porepressure and particle assemblage. Where the shear stress field is low, as in deep troughs, a marine glacier may slide across the seafloor, with or without deforming the surficial units of the underlying strata (Andrews and Matsch, 1983). Where the shear stress field is higher, till may be deposited. important parameters include basal ice velocity and basal ice temperature. Where the basal temperature is warm and ice velocity low, till can be deposited beneath the ice mass. The time an ice sheet has occupied a given location is important in determining the amount of sediment entrained into, or deposited below, the forward moving ice mass.

Thus we envisage a range of initial glacial conditions between two end-member cases (Fig. 13). In the first case, ice is focused through an ice corridor so as to advance rapidly into deep water, overriding and partly preserving the integrity of the previously deposited marine sediment (Fig. 14a, cf. Fig. 6). This is particularly appropriate for ice conduits flowing into deep troughs like those that dissect many of the world's glaciated continental shelves. In the second case, a thicker ice sheet advances more slowly along a broad front and onto shallower shelves so that previously deposited marine sediment is entrained into the base of the ice sheet (Fig. 14b, cf. Fig. 3a).

\section{STAGE 2 - TERMINAL ICE DYNAMICS}

Ice sheets respond to a change in their equilibrium line (ELA) elevation by adjusting their terminus elevation. This simplistic view is complicated when part or all of an ice sheet's terminus is at sea level - a fall in the ELA can not be directly accommodated by a change in the terminus elevation once it has reached sea level, and the vertical distance between the firn limit and the terminus (sea level) will decrease. The

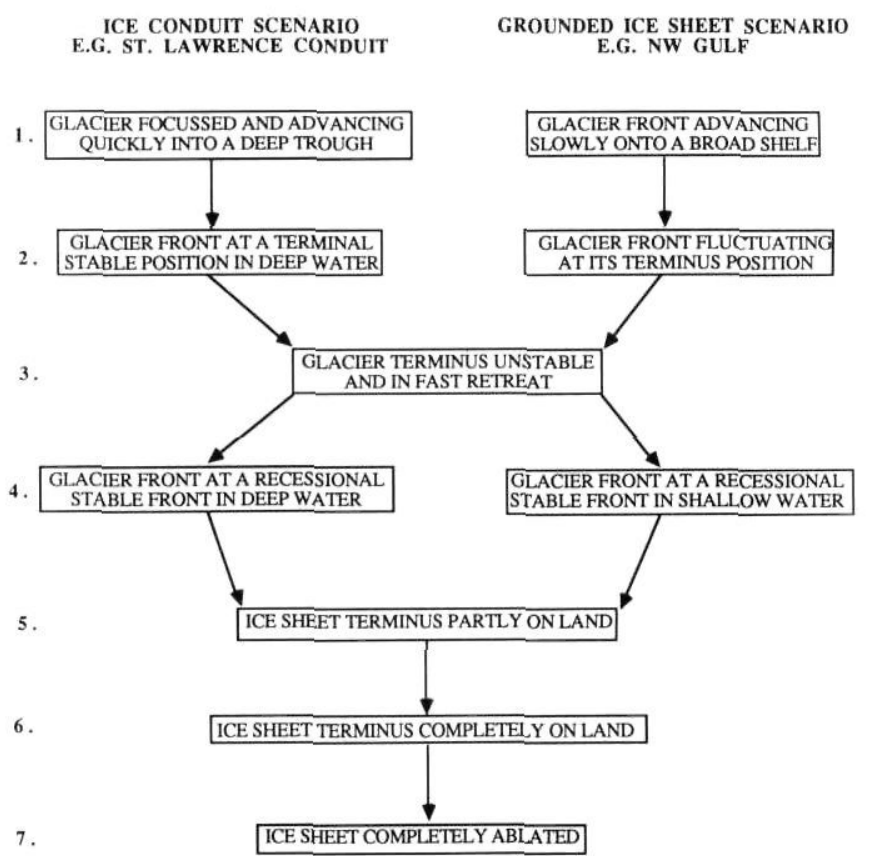

FIGURE 13. The seven stages of an ice conduit and ice sheet advance-retreat that will affect or contribute to the sedimentation onto a continental shelf (cf. Fig. 14 and text for details).

Les sept stades de l'avancée et du retrait d'un inlandsis, qui auraient influencé la sédimentation sur le plateau continental ou qui y auraient contribué.

final terminal position of a tidewater ice sheet depends more on the rate of ice discharge balanced by the rates of calving plus ablation (Syvitski, 1989). If we consider that water depth is the critical factor for controlling the rate of iceberg calving (Meier, 1988), then changes in the offshore bathymetry coupled with ELA changes control the terminal position of an advancing marine ice sheet.

Therefore we suggest two end-member cases for the terminal position of a marine ice sheet (Fig. 13). In the ice conduit case, where a glacier is focused into a deep basin or trough, a stable terminal position can be maintained only if: (i) the ice discharge is relatively constant and balanced by an appropriate calving/ablation rate occurring at a particular water depth and trough position, and (ii) relative sea level is not fluctuating (as fluctuations will affect the calving rate: M. Meier, pers. comm., 1988). The longer the ice front can maintain a stable position the more sediment will be deposited (Fig. 14c, cf. Fig. 7a). The deposits will range from a frontal-dump (terminal) moraine grading into ice-proximal and then into icedistal sediments. In the case of an ice sheet advancing onto an open continental shelf, a stable marine terminus position is very difficult to obtain, as the ice sheet terminus will be fed by many ice corridors flowing onto a variable shelf bathymetry. Each ice corridor will have its own semi-independent velocity and one glacier temporarily cutting across the path of a neighbouring glacier is well documented (Syvitski, 1987). Thus the likelihood of a stable terminal position would be low and the possibility of episodic advances and retreats would be high - one might expect ice front movement over portions of the 

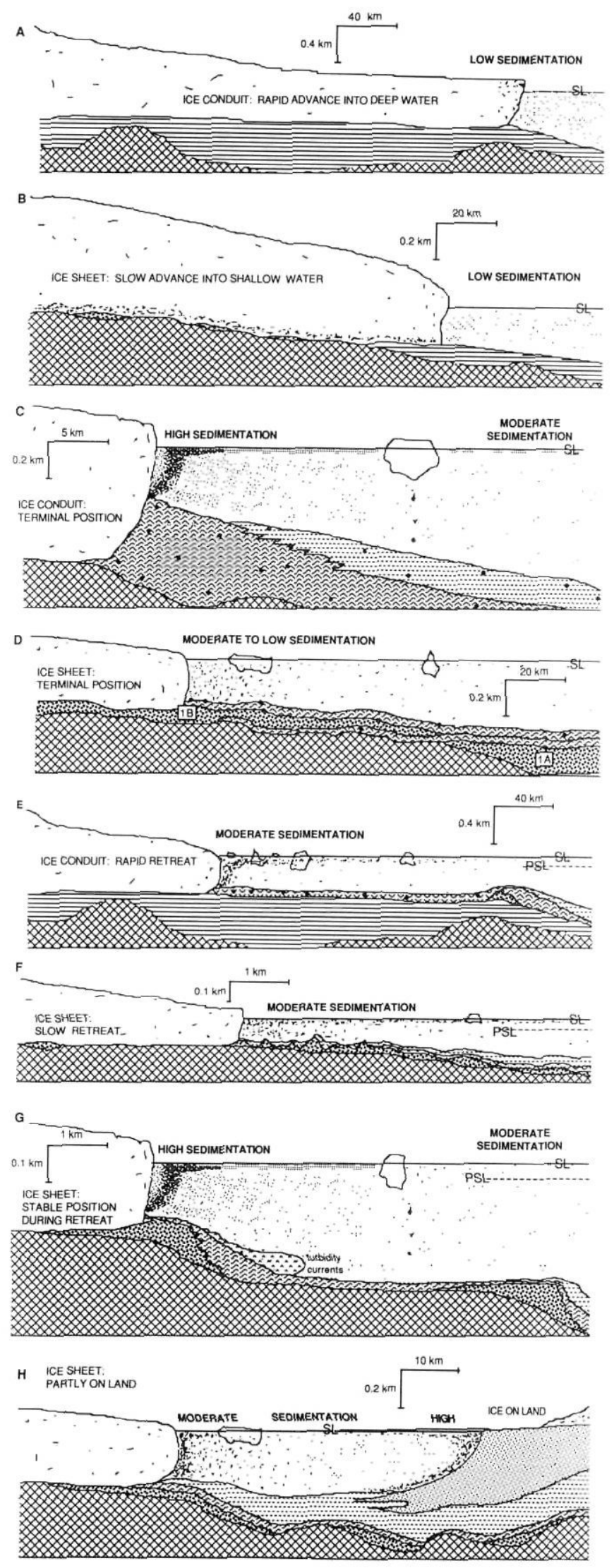

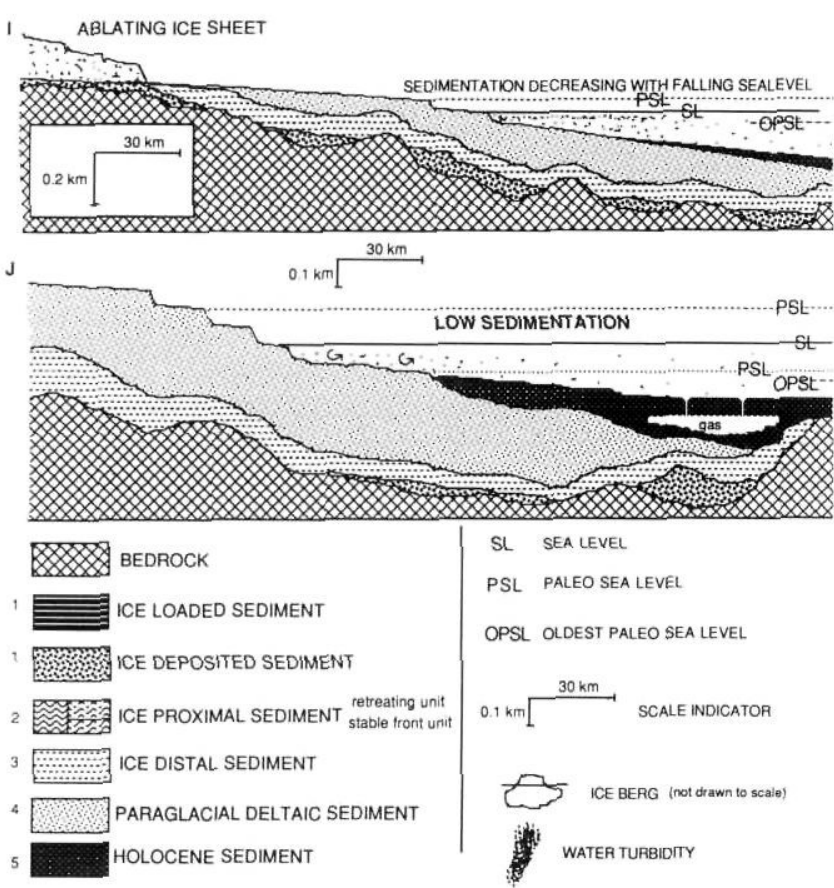

FIGURE 14. A conceptual model of glacier sediment interactions (see text for details). A: See also Figure 6; B: see also Figure 3A; C: see also Figure 7A; D: see also Figure 5; E: see also Figure 6A and $7 A ; F$ : see also Figure $3 B ; G$ : see also Figure $4 ; \mathrm{H}$ : see also Figure $8 \mathrm{~A} ; \mathrm{I}$ : see also Figure 9 and $15 \mathrm{~A}$; J: see also Figure $11 \mathrm{C}$ and $\mathrm{D}$.

Modèle représentant l'interaction du glacier et des sédiments (voir détails dans le texte). A: Voir figure $6 ; B$ : voir figure $3 A ; C$ : voir figure $7 A ; D$ : voir figure $5 ; E$ : voir figure $6 A$ et $7 A ; F$ : voir figure $3 B$; $\mathrm{G}$ : voir figure $4 ; \mathrm{H}$ : voir figure $8 \mathrm{~A} ; \mathrm{l}$ : voir figure 9 et $15 \mathrm{~A} ; \mathrm{J}$ : voir figure $11 C$ et $D$.

shelf from more than one direction. In such a scenario, both ice contact and ice proximal units could be preserved from glaciers that crossed each others' path (Fig. 14d, cf. Fig. 5).

\section{STAGE 3 - UNSTABLE ICE TERMINUS RETREAT}

The dominant external process affecting the relative height of mean sea level is glacial growth and decay. As ice sheets form, geodetic sea level falls because of eustatic processes. However, relative sea level rises as the land is depressed to an even further extent under the newly formed ice load. Sea level will adjust its position against the tidewater ice sheet terminus. There may be a critical period when the depression of the crust near the ice terminus position will excede the eustatic lowering of sea levels (Syvitski et al., 1987b). The rise in relative sea level along the ice front may be sufficient to destablize the terminus and increase the rate of calving. Ice conduits flowing into deep troughs are sensitive to buoyancy fluctuations and would experience fast retreat rates. Retreat rates along the terminus of an ice sheet would be more variable, depending on the distribution of basins and banks.

High retreat rates are not conducive to the generation of ice contact deposits, such as push moraines (Boulton, 1986), but are conducive to the preservation of subglacial features such as eskers and drumlins and even sole markings on the 
surface of ice-loaded sediment. Thus the generation or preservation of ice contact deposits depends on the retreat rate of the ice terminus. The distribution and thickness of the iceproximal unit (2), deposited above the ice-loaded or icedeposited unit, would depend on: (i) the rate of ice front retreat, and (ii) the number and location of ice front discharge outlets. Where the number of outlets is high, and the retreat rate rapid, the ice proximal unit will be deposited as a coarsegrained blanket conformable to the underlying morphology, whether that consists of ice-loaded or ice-deposited units (Fig. 14e, cf. Figs. 6a and 7a). If the retreat rate is slow, the ice proximal unit may be affected by seasonal fluctuations of the position of the ice margin and push moraines would be preserved (Fig. 14f, cf. Fig. 3b).

The thickness and distribution of the ice distal unit (3) will depend on the same factors controlling the distribution of unit 2 , except that unit 3 will be much more sensitive to the dynamics of water movement, both proximal and distal to the ice terminus. Among the many controls on the circulation within a glacial sea are: (i) the intensity of winds blowing off an ice sheet, i.e. affecting wind-drift and the generation of waves, (ii) the available fetch which is intimately linked to the critical depth of wave erosion - as the ice retreats the fetch, and thus the wave base, will increase, (iii) the tidal prism - tidal conditions during the Late Wisconsinan are known to differ from those observed today, (iv) water stratification - with an order-ofmagnitude increase in the discharge of fresh water into the coastal zone, and a delivery period of 4 to 6 months (cf. a modern freshet delivery of 1 to 2 months), the glacial sea would be highly stratified and bottom currents greatly reduced, (v) water depth - in a deeper glacial sea the wave base would be moved shoreward - and (vi) the normal forces that govern the movement of a buoyant hypopycnal plume, including Coriolis and centrifugal accelerations.

\section{STAGE 4 - STABLE ICE FRONT DURING THE RECES-} SIONAL PHASE

A retreating ice sheet may attain a tidewater equilibrium position at convenient topographic configurations (Lliboutry, 1965), including a narrowing of a trough or rapid change in the bathymetric slope. A stable ice front will generate a marine ice contact fan or frontal dump moraine, whose size will depend on: (i) the duration that the glacier can maintain the stable front, (ii) the supply of sediment to the ice front through glacial and glaciofluvial processes, and (iii) the oceanic processes that work to disperse the sediment deposited at the ice front. Also, the deeper the original water depth at the onset of the ice equilibrium position, the thicker the marginal deposits can grow (assuming constant sediment delivery). This also provides an important feedback loop whereby the high sedimentation rates at the ice front, which can exceed a metre per year (Syvitski et al., 1987b), may decrease the calving rate and thus increase the stability of the ice front (Fig. 14c, cf. Fig. 7a). Sedimentation rates decrease exponentially away from a tidewater ice front associated with a concommittant decrease in grain size (Syvitski, 1989), i.e. unit 2 grading into unit 3.

In the case of an ice sheet advancing onto an open continental shelf, the through-ice sediment delivery of a tidewater ice sheet is dispersed over a wider front. Thus the size of the frontal moraines are smaller, in terms of height and width, although the deposits are volumetrically significant because of their great length (Fig. $14 \mathrm{~g}$, cf. Fig. 4). Their number and location will depend on the bathymetric complexities found on the shelf. Also, the sediment plumes will not be focused by trough walls but will be subject more to coastal drift along the ice sheet (Pfirman and Solheim, in prep.). Thus unit 3 will be deposited much closer to the ice front than in the ice conduit scenario.

\section{STAGE 5 - ICE SHEET PARTLY ON LAND}

Because the crustal response to an ice sheet is generally slow compared to the ice retreat rate (Syvitski et al., 1987b), the sea will transgress the coastal zone as the ice retreats, and for distances occasionally in excess of $100 \mathrm{~km}$. Only in the most simplistic of coastal configurations will the terminus of an ice sheet withdraw from the sea evenly across its entire length. Thus there will be a period when a portion of an ice front will be tidewater and a portion subaerial. During this period, offshore basins will receive sediment from: (i) icedistal hemipelagic sedimentation under the buoyant surface plumes issuing from the front of the tidewater ice sheet (unit 3), and (ii) paraglacial mass flow deposition (unit 4) from failed foreset faces and prodelta regions of sandur deposits actively prograding into the glacial sea in front of the subaerial ice sheet (Fig. 14h, cf. Fig. 8a). Where hemipelagic sedimentation is conformable, the integrity of offshore basins is maintained. However, mass transport by slides and turbidity currents associated with the deposition of unit 4 combine to fill bathymetric depressions.

\section{STAGE 6 - ICE SHEET ABLATING TOTALLY ON LAND}

At the marine maximum (marine limit), sediment is deposited rapidly on top of the glacial and glaciomarine sediments (units 1,2 and 3), as a prograding deltaic wedge, and at rates that are abnormally high for the local climate-induced discharge (Fig. 14i, cf. Figs. 9 and 15a). Thus, this stage of paraglacial sedimentation involves the seaward progression of basins being filled, and continues the smoothing out of irregularities in the coastal bathymetry. The sediment flux from land to sea is very high, both from the increased discharges tied to the ablating ice masses and the vast quantity of available proglacial sediment fronting the ice sheet. This form of marine sedimentation continues concommittant with isostatic uplift, which in turn increases the gradient of the rivers and thus the seaward flux of sediment. The newly exposed marine deposits become incised and the organic-poor clays become leached of salts and more sensitive. Both contribute to the failure of fluvial terraces which in turn increases the land-sea flux of sediment.

Paraglacial sedimentation does not affect all parts of the nearshore and shelf, but only those areas under the direct influence of river plumes. As the ice recedes from the smaller drainage basins, rivers will become isolated from the effects of the melting ice cap. In areas outside the influence of coastal rivers, there will be a vertical gradation of unit 3 , the ice distal clays, into unit 5 , the postglacial clays. 


\section{STAGE 7 - ICE SHEET FULLY ABLATED}

Eventually the hinterland denudation rates and the flux of sediment from land to sea returns to normal. Sea levels also approach modern conditions, in a diachronous and fluctuating pattern related to the returning (landward directed) crustal forebulge generated from the relaxing of the ice load and as influenced by local diastrophic conditions. Some areas of the coast will experience only uplift, while others areas will endure both uplift and subsidence. The distribution of erosional surfaces and sediment lags will be closely linked to the pattern of relative sea level fluctuations. With lowered sea levels, the intensity of bottom currents will increase. Water stratification on the shelf will decrease dramatically as the ablation discharge disappears. Zones of upwelling will increase with the reduced water stratification and increase in bottom currents. In response to sedimentation under smaller and less turbid river plumes, basin fill patterns associated with unit 5 will reflect more the erosion of sediment from shallow platforms and the generation of onlap sequences within coastal basins (Fig. 14j, cf. Figs. 9b and 11c). Sediment rafting from sea ice will replace that from icebergs. Vegetation, now abundant on land, will increase the flux of carbon into coastal basins. Marine carbon production will also increase, no longer affected by the light limiting turbid plumes once flowing out from the ice sheets. The generation of methane and other low temperature gases will be concommittant with this increased vertical flux of carbon to the seafloor. As a result, gas pockets will form within the sediment, and gas escape features will form at the seafloor (Fig. 14j, cf. Fig. 11c and 11d).

\section{SUMMARY}

We have identified five regional seismo-stratigraphic units which can be recognized over a very large area (Fig. 15). These units appear to relate to the advance or retreat of the Late Wisconsinan Ice Sheet. A conceptual model dealing with the deposition of sediment during a glacial - interglacial stage is proposed, as an aid in the interpretation of these regional units. The lowermost unit 1 records the presence of grounded glacial ice such as linear ice marginal deposits (e.g. frontal-dump moraines, push moraines), subglacial deposits (e.g. eskers and/or drumlins, till), and pre-Late Wisconsinan sediments loaded by the Late Wisconsinan ice advance. These latter deposits can exceed $200 \mathrm{~m}$ in thickness. In some areas unit 1 contains several layers which may relate to multiple glacial advances during one or more glacial cycles.

An ice-proximal unit 2 overlies unit 1 and includes a widespread conformable facies interpreted as deposition during the rapid retreat of an ice terminus, and a wedge-shaped facies (up to $160 \mathrm{~m}$ thick at the head of the Laurentian Trough) that is particularly common to areas of ice marginal still stand deposits. We associate unit 2 with high energy, depositional processes associated with a major outlet along the face of a glacier. Absence of unit 2 may indicate a period of rapid ice front retreat through much of the Gulf, or more locally, distance away from a discharge outlet.

We relate the highly conformable unit 3 , to ice-distal deposition of fine-grained sediment under highly turbid buoyant

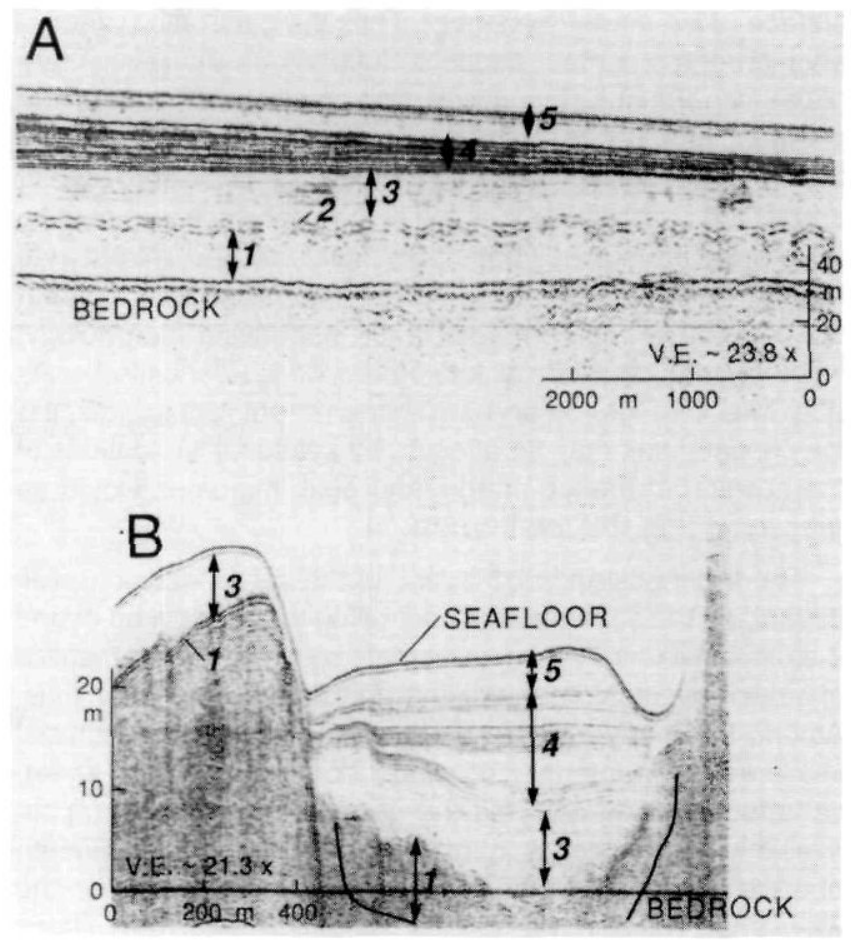

FIGURE 15. Two type sections collected $800 \mathrm{~km}$ apart, showing the same seismo-stratigraphic units. In both cases unit 2 is poorly represented. A: A typical section along the St. Lawrence Estuary, and (B) a typical section off Sept-îles.

Deux profils types obtenus à $800 \mathrm{~km}$ l'un de l'autre et révélant les mêmes unités sismo-stratigraphiques. Dans les deux cas, l'unité 2 est faiblement représentée. A: profil type le long de l'estuaire du Saint-Laurent; B: profil type au large de Sept-Îles.

glacial plumes, during a period of elevated sea levels and a rapidly ablating ice sheet. The land equivalent is the raised marine Goldthwait Sea deposits of stratified glacial clay. The deposits thicken towards the upper St. Lawrence Estuary and the equivalent Saguenay Fjord deposits exceed $500 \mathrm{~m}$.

Unit 4 is acoustically well-stratified and highly reflective. It represents the paraglacial period of local land drainage and deltaic progradation during the melting of terrestrial-based ice caps and rapidly falling sea levels. The lower portion of the unit may interfinger with unit 3 suggesting a limited presence of both terrestrial and tidewater glacier fronts. The unit contains a complex of failed sediment masses, gravity flow deposits and structures, and hemipelagic deposits. The unit exceeds $100 \mathrm{~m}$ near the margins of the north shore of the Gulf.

Unit 5 acoustically is highly variable both regionally and locally. The unit reflects the winnowing of sediment from shallow areas and deposition of organic-rich mud in deep basins, under modern sea level and oceanographic conditions, and a decreasing sediment supply through the Holocene. Unit 5 exceeds $100 \mathrm{~m}$ in thickness in the Lower St. Lawrence Estuary and the upper Saguenay Fjord. The presence of gas in unit 5 , reflects the increased carbon flux from land and marine sources during the Holocene.

Our geologic interpretation of the sediments within the St. Lawrence Estuary and adjoining areas is compatible with the 
sequence of terrestrial Quaternary events outlined by Dyke and Prest (1987), except we suggest that the Laurentide Ice conduit reached a terminal position farther seaward. We have constrained our seismo-stratigraphy using terrestrial data on the timing of the advance and retreat of the Laurentide Ice Sheet and the resultant fluctuations in relative sea level. However, every unit, except perhaps unit 5 , the postglacial sedimentary deposits, were deposited in a diachronous manner, depending on fluctuations in the position of the ice terminus. Considerable effort in future coring and dating will be necessary to provide a reliable and regional chrono-stratigraphy for such diachronous deposits.

We argue that an ice conduit, flowing through the Laurentian Trough, advanced over and preserved pre-Late Wisconsinan, marine sediment occupying the Trough (Figs. 13 and 14a). However, along the margins of the Trough, the Laurentide Ice Sheet appears to have been capable of eroding and entraining unconsolidated marine sediment (Figs. 13 and 14b), so that bedrock was in contact with ice. During the retreat phase, which included a stable position at the head of the Trough and along its margins, a wide variety of submarine ice contact deposits were laid down by the ice sheet, including frontal dump moraines and ice contact fans, possible eskers or drumlins, till, and push moraines.

In order of importance, the Late Wisconsinan events that contributed the largest marine deposits include:

1. The $13 \mathrm{ka}$ still stand of the Laurentian Ice Conduit, situated at the head of the present-day Laurentian Trough, whereby much of the ice proximal and ice distal sediment now found in the St. Lawrence Estuary was deposited (stage 4 of our model).

2. The Goldthwait Sea, located in the NW Gulf and Estuary between 13 and $11 \mathrm{ka}$, and in the Saguenay Fjord between 11 and $8.4 \mathrm{ka}$, wherein enormous volumes of glacial silt and clay were deposited under ice-distal plumes (stages 4 through 5).

3. The prograding paraglacial deltas, that filled paleofjord basins situated along the north shore of the Gulf, between 11 to $7 \mathrm{ka}$, and locally advanced the shoreline into the presentday St. Lawrence Estuary (stages 5 through 6).

4. The Holocene deposition of organic-rich mud in deepwater basins of the St. Lawrence Estuary, the Saguenay Fjord and Gaspé estuaries including Baie des Chaleurs (stage 7).

Stages 1 through 3 of our model did not produce significant offshore glaciomarine deposits, except locally.

\section{ACKNOWLEDGEMENTS}

We thank the officers and crew of the C.S.S. Dawson and the Louis M. Lauzier for their professionalism. The quality of the seismic records owes much to $G$. Standen (Seakem Oceanographic), P. Conolly (Huntec), and D. Locke (AGC/ GSC). Also the technical assistance of Program Support (AGC), including T. Atkinson, D. Beaver, R. Currie, I. Hardy, R. Murphy, J. Neilsen, and A. Sherin, and the EMG technical support, including K. Asprey, D. Beattie, J. Burns, W. LeBlanc, S.
Hoskins, and K. Robertson, are given honourable mention. Scientific support was provided by Drs. L. Dredge, J. Locat, B. D'Anglejan, B. Long and C. Schafer. We appreciate the critical comments and reviews of B. Long, G. Vilks, B. MacLean.

\section{REFERENCES}

Andrews, J. T. and Matsch, C. L., 1983. Glacial marine sediments and sedimentation: An annotated bibliography. GEO Abstracts No. 1, Short Run Press, Exeter.

D'Anglejan, B. F. and Brisebois, M., 1974. First subbottom acoustic reflector and thickness of recent sediments in the upper estuary of the St. Lawrence River. Canadian Journal of Earth Sciences, 11: 232-245.

D'Anglejan, B. F. and Brisebois, M., 1978. Recent sediments of the St. Lawrence middle estuary. Journal of Sedimentary Petrology, 48: 951-964.

Boulton, G. S., 1975. Processes and patterns of subglacial sedimentation : a theoretical approach. In A. E. Wright and F. Moseley, ed., Ice Ages: Ancient and Modern. Geological Journal Special Issue, 6: 7-42.

1986, Push-moraines and glacier contact fans in marine and terrestrial environments. Sedimentology, 33: 677-698.

Boulton, G. S. and Eyles, N., 1979. Sedimentation by valley glaciers: A model and genetic classification, p. 11-25. In C. Schliichter, ed., Moraines and Varves. Proc. of the 1978 INQUA symposium on the Genesis and Lithology of Quaternary Deposits.

Boulton, G. S., Dickson, J. H., Nichols, H., Nichols, M. and Short, S. K., 1976. Late Holocene glacier fluctuations and vegetation changes at Maktak Fiord Baffin Island, N.W.T. Arctic and Alpine Research, 8: 343-356.

Church, M. and Ryder, R. M., 1972. Paraglacial sedimentation: A consideration of fluvial processes conditioned by glaciation. Geological Society of America, 83: 3059-3072.

Dionne, J.-C., 1972. Caractéristiques des blocs erratiques des rives de l'estuaire du Saint-Laurent. Revue de Géographie de Montréal, 26: 125-152.

1988. L'émersion de la côte sud du Saint-Laurent depuis la dernière glaciation. GEOS, 17: 18-21.

Douglas, R. J. W., 1970. Geological Map of Canada. Geological Survey of Canada Map No. 1250A.

Dredge, L., 1983. Surficial Geology of the Sept-Îles area, Quebec North Shore. Geological Survey of Canada Memoir 408, 40 p.

Dyke, A. S. and Prest, V. K., 1987. Late Wisconsinan and Holocene history of the Laurentide Ice Sheet. In R. J. Fulton and J. T. Andrews, ed., The Laurentide Ice Sheet. Géographie physique et Quaternaire, 41: 237-264.

Fader, G. B., King, L. H. and Josenhans, H. W., 1982. Surficial geology of the Laurentian channel and the western Grand Banks of Newfoundland. Geological Survey of Canada, Paper 81-22, $37 \mathrm{p}$.

Görlich, K., Weslawski, J. M. and Zajaczkowski, M., 1987. Settling of clay suspension and bottom fauna biomass in Hornsund Fjord, Spitsbergen. Polar Research, 5: 175-192.

Gratton, Y., Mertz, G. and Gagné, J. A., 1988. Satellite observations of tidal upwelling and mixing in the St. Lawrence Estuary. Journal of Geophysical Research, 93: 6947-6954.

Hamilton, E. L., 1985. Sound velocity as a function of depth in marine sediments. Journal of the Acoustical Society of America, 78: 13481355. 
Hein, F. J. and Syvitski, J. P. M., 1988. Evolution of Sept-lles delta complexes and shallow marine placer, North Shore of Gulf of St. Lawrence. Geological Association of Canada Annual Meeting, St. John's, Newfoundland, May 23-25, 1988, p. A54.

Hoskin, K. S., Syvitski, J. P. M., Asprey, K. W. and Connolly, P., 1984. Expedition report No. 84-025, Louis M. Lauzier, Centre Champlain des Sciences de la Mer, October 19-21, 1984. Geological Survey of Canada, unpublished report.

Hutchins, R. W., McKeown, D. L. and King, L. H., 1976. A deep tow high resolution seismic system for continental shelf mapping. Geoscience Canada, 3: 95-100.

Josenhans, H. W., Zevenhuizen, J. and Klassen, R. A., 1986. The Quaternary geology of the Labrador Shelf. Canadian Journal of Earth Sciences, 23: 1190-1213.

Keen, M. J. and Piper, D. J. W., 1976. Kelp, methane, and an impenetrable reflector in a temperate bay. Canadian Journal of Earth Sciences, 13: 312-318.

King, L. H. and Fader, G. B., 1986. Wisconsinan glaciation of the Atlantic continental shelf of southeast Canada. Geological Survey of Canada, Bulletin 363, $72 \mathrm{p}$.

LaSalle, P., 1984. Quaternary stratigraphy of Québec: A review, p. 155-171. In R. J. Fulton, ed., Quaternary Stratigraphy of Canada - A Canadian Contribution to IGCP Project 24. Geological Survey of Canada, Paper 84-10.

Lliboutry, L., 1965. Glaciers, variations du climat, sols gelés, p. 429504, 517-520, 680-682, 763-764. In Traité de glaciologie, Masson, Paris.

Locat, J., Lefebvre, G. and Ballivy, G. 1984. Mineralogy, chemistry, and physical properties interrelationships of some sensitive clays from Eastern Canada. Canadian Geotechnical Journal, 21: 530540.

Loring, D. H., 1975. Surficial geology of the Gulf of St. Lawrence, p. 11-30. In W. J. M. van der Linden and J. A. Wade, ed., Offshore Geology of Eastern Canada - Volume 2 - Regional Geology. Geological Survey of Canada, Paper 74-30.

Loring, D. H. and Nota, D.J.G., 1973. Morphology and sediments of the Gulf of St. Lawrence. Fisheries Research Board of Canada, Bulletin 182, $147 \mathrm{p}$.

Mertz, G., El-Sabh, M. I., Proulx, D. and Condal, A. R., 1988. Instability of a buoyancy-driven coastal jet: The Gaspé Current and its St. Lawrence precursor. Journal of Geophysical Research, 93 : 68856893.

Nardin, T. R., Hein, F. J., Gorsline, D. S. and Edwards, B. D., 1979 A review of mass movement processes, sediment and acoustic characteristics and contrasts in slope and base-of-slope systems versus canyon-fan-basin floor systems. Society of Economic Paleontologists and Mineralogists Special Publication, 27: 61-73.

Pfirman, S. and Solheim, A., 1989. Subglacial meltwater discharge in the open marine tidewater glacier environment: Observations from Nordaustlandet, Svalbard Archipelago. Marine Geology, 86: 265-281.

Piper, D. J. W., Letson, J. R. J., Delure, A. M. and Barrie, C. Q., 1983. Sediment accumulation in low-sedimentation, wave-dominated. glaciated inlets. Sedimentary Geology, 36: 195-215.

Praeg, D. B., d'Anglejan, B. F., and Syvitski, J. P. M., in prep. Quaternary dynamics of the Charlevoix deltas and Upper St. Lawrence Estuary.
Praeg, D. B., MacLean, B., Hardy, I. A. and Mudie, P. J., 1986. Quaternary geology of the southeast Baffin Island continental shelf. Geological Survey of Canada, Paper 85-14, $38 \mathrm{p}$.

Praeg, D. B., Syvitski, J. P. M., Asprey, K., Currie, R., Hein, F., Miller, A., Sherin, A. and Standen, G., 1987a. Report of CSS Dawson cruise 87-023 in the Gulf of St-Lawrence. Geological Survey of Canada, Open File Report 1678, 84 p

Praeg, D. B., Syvitski, J. P. M., Schafer, C. T., Johnston, B. L. and Hackett, D. W., 1987b, CSS Dawson 86-016 cruise report. Geological Survey of Canada, Open File Report 1412, 44 p.

Schafer, C. T. S., Cole, F. E. and Syvitski, J. P. M., 1989. Bio and lithofacies of modern sediments in Knight and Bute Inlets, British Columbia. Paliaos, 4: 107-126.

Solheim, A. and Pfirman, S. L., 1985. Sea-floor morphology outside a grounded, surging glacier, Bråsvellbreen, Svalbard. Marine Geology, 65 : 127-143.

Smith, J. N. and Schafer, C. T., 1987. A 20th-century record of climatologically modulated sediment accumulation rates in a Canadian Fiord. Quaternary Research, 27: 232-247.

Smith, J. N. and Walton, A. 1980. Sediment accumulation rates and geochronologies measured in the Saguenay Fjord using Pb-210 dating method. Geochimica et Cosmochimica Acta, 44: 225-240.

Syvitski, J.P. M., 1986. Estuaries, Deltas and Fjords of Eastern Canada. Geoscience Canada, 13: 91-100.

1987. Airphoto interpretation of changes to the tidewater position of glaciers and deltas along the NE Baffin coast. Geological Survey of Canada Open File Report 1589, Chapter 4, 11 p.

1988. DAWSON 88-088 technical cruise summary. Geological Survey of Canada, Open File Report 1920, 60 p.

1989. On the deposition of sediment within glacier-influenced fjords: Oceanographic controls. Marine Geology, 85: 301-329.

Syvitski, J. P. M. and Farrow, G. E., 1989. Fjord sedimentation as an analogue for small hydrocarbon-bearing fan deltas, p. 21-43. In M. K. G. Whateley and K. T. Pickering, ed., Deltas - Sites and Traps for Fossil Fuels. Special Publ. 41, Geological Society of London 1.

Syvitski, J. P. M., Silverberg, N., Ouellet, G. and Asprey, K. W., 1983a. First observations of benthos and seston from a submersible in the Lower St. Lawrence Estuary. Géographie physique et Quaternaire, 37: 227-240.

Syvitski, J. P. M., Fader, G. B., Josenhans, H. W., MacLean, B. and Piper, D. J. W., 1983b. Seabed investigations of the Canadian east coast and arctic using Pisces IV. Geoscience Canada, 10: 59-68.

Syvitski, J. P. M., Beattie, D. D., Praeg, D. B. and Schafer, C. T., 1987a. Marine geology of Baie des Chaleurs. Geological Survey of Canada, Open File Report 1375.

Syvitski, J. P. M., Burrell, D. C. and Skei, J. M., 1987b. Fjords: Processes and Products. Springer-Verlag, New York, 379 p.

Syvitski, J. P. M., Smith, J. N., Calabrese, E. A. and Boudreau, B. P., 1988. Basin sedimentation and the growth of prograding deltas. Journal of Geophysical Research, 93: 6985-6908.

Vilks, G., Deonarine, B. and Winters, G., 1987. Late Quaternary marine geology of Lake Melville, Labrador. Geological Survey of Canada, Paper 87-22, 49 p. 